\title{
Quality Assessment of Groundwater with Special Emphasis on Irrigation and Domestic Suitability in Suri I \& II Blocks, Birbhum District, West Bengal, India
}

\author{
S. K.Nag*, Shreya Das \\ Department of Geological Sciences, Jadavpur University, Kolkata, India \\ *Corresponding author: nag_sk@yahoo.com
}

Received July 01, 2014; Revised July 14, 2014; Accepted August 27, 2014

\begin{abstract}
The hydrochemical study of groundwater samples was carried out from the Suri I and II blocks of Birbhum district, West Bengal (latitudes $23.76^{\circ} \mathrm{N}-23.99^{\circ} \mathrm{N}$ and longitudes $87.42^{\circ} \mathrm{E}-87.64^{\circ} \mathrm{E}$ ) with an objective of understanding the suitability of local groundwater quality for irrigation and domestic purposes. For this study groundwater samples were collected from 26 (twenty six) locations during the post monsoon and pre monsoon sessions spanning over 2012 and 2013. Groundwater samples were analyzed for their physical and chemical properties using standard laboratory methods. From the analyzed data, some parameters like SAR, SSP, RSC, MAR, PI and KR have been calculated for each water sample to identify the irrigational suitability. Accordingly, the groundwater has been found to be well to moderately suitable for irrigation. In the post monsoon session exceptionally high RSC values for around $80 \%$ samples indicate an alkaline hazard to the soil. The ion balance histogram for post monsoon indicates undesirable ion balance values according to fresh water standards whereas in pre monsoon, the samples show good ion balance in water. The Piper's trilinear diagram used to determine water type suitable for consumption indicates groundwater in the study is of bicarbonate type (fresh type) in both and pre monsoon with exception of a couple of sulfate type samples during pre monsoon. Water Quality Index results depict $90 \%$ of water samples are suitable for drinking during post monsoon whereas in pre monsoon that tally comes down $60 \%$ rendering $40 \%$ samples unsuitable for drinking. Gibb's diagrams prepared for the post monsoon and pre monsoon sessions indicate that the overall hydrogeochemistry of the study area is dominated by rock - water interaction processes.
\end{abstract}

Keywords: groundwater quality, irrigation and domestic suitability, ionic balance, Gibb's diagram, Suri I and II Blocks, Birbhum district, West Bengal

Cite This Article: S. K.Nag, and Shreya Das, "Quality Assessment of Groundwater with Special Emphasis on Irrigation and Domestic Suitability in Suri I \& II Blocks, Birbhum District, West Bengal, India.” American Journal of Water Resources, vol. 2, no. 4 (2014): 81-98. doi: 10.12691/ajwr-2-4-2.

\section{Introduction}

Scarcity of water is becoming a burning problem in India. This is particularly true especially in the arid and semi-arid regions of the country due to vagaries of monsoon and scarcity of surface water. Over the last few decades, competition for economic development, associated with rapid growth in population and urbanization, has brought in significant changes in land use, resulting in more demand of water for agriculture, domestic and industrial activities.

In India, about $50 \%$ of the total irrigated area is dependent on groundwater irrigation [1] and according to FAO [2], groundwater constitutes about $53 \%$ of the total irrigation potential of the country and sixty percent of irrigated food production is from groundwater wells [3]. All these are responsible for the overexploitation of this precious natural resource in several parts of the country resulting in declining groundwater level. Besides decline in water level, groundwater quality is also deteriorating in many parts of the country. The monitoring of water quality has gained its importance for sustainable development and proper management of this precious natural resource.

The importance of water quality in human health has recently attracted a great deal of interest. In the developing world, $80 \%$ of all diseases are directly related to poor drinking water and unsanitary conditions [4]. Assessment of groundwater quality is essential for particularly water from those sources which serve as drinking water sources. Groundwater quality has been deteriorating over the last few decades due to massive rise in rate of industrialization and population $[5,6]$. Chemical composition of the water consumed can immediately or eventually lead to innumerable physiological ailments in humans. A vast amount of study and research over the last few years have led to understanding the degrading groundwater quality and thus has brought to forefront the consequences $[7,8,9]$. Various environmental indices and parameters are now being used to ascertain quality of water leading to 
determination of its suitability for domestic and irrigational purposes [10].

Evaluation of groundwater quality is a necessary and immediate task for present and future groundwater quality researchers. Groundwater quality depends on number of factors - (i) general geology, (ii) degree of chemical weathering of the various rock types, (iii) quality of recharge water and (iv) inputs from sources other than water-rock interaction [11,12]. Such factors and their interactions are responsible for complex groundwater quality [13]. Many research publications have come out on evaluation for domestic and industrial activities and related groundwater quality monitoring $[6,14,15,16,17,18]$. In a previous study high salinity and nitrate in groundwater have been reported from Wuwei basin, northwest China [19]. Groundwater chemistry is influenced by the lithology and anthropogenic activity [18] in Salem district of Tamil Nadu, India. In Uttar Pradesh, India geochemical facies and locations unfit for human consumption have also been demarcated [20]. In Guntur of Andhra Pradesh delineation of groundwater zones have been made on the basis of water quality [21]. Studying classification of groundwater has been attempted in Bangladesh [22] and in South Africa [23] suggesting groundwater suitability for drinking and public health. Similar studies based on groundwater quality and hydrogeochemistry have been taken up by many researches in different parts of the globe [15,24-33].
Routine applications of fertilizers on crop fields cause contamination of groundwater as well as accumulation of the nutrients in groundwater. Several researchers evaluated the suitability of groundwater for irrigation quality [34,35,36,37,38]. Total dissolved solids (TDS) values are also considered as an important parameter in determining the usage of water, and groundwater with high TDS values are not suitable for both irrigation and drinking purposes [39].

A detailed geochemical study was carried out to identify groundwater contamination processes in the Suri - I and II blocks of Birbhum district, West Bengal. The present study focuses on ascertaining the irrigational suitability and potability standards of groundwater in the study area. Population has almost doubled within a span of two decades in this district directly resulting in a rise in irrigation and micro scale industries. Water required for all these activities is sourced from the groundwater reserves, which is deteriorating in quality due to manmade tampering. Besides anthropogenic activities, natural phenomena such as weathering of rocks and dissolution of minerals and climate changes also lead to release of certain elements into water, the excess of which on consumption turns detrimental [40]. The present study intends to highlight such issues if any; for future implementation of preventive measures.

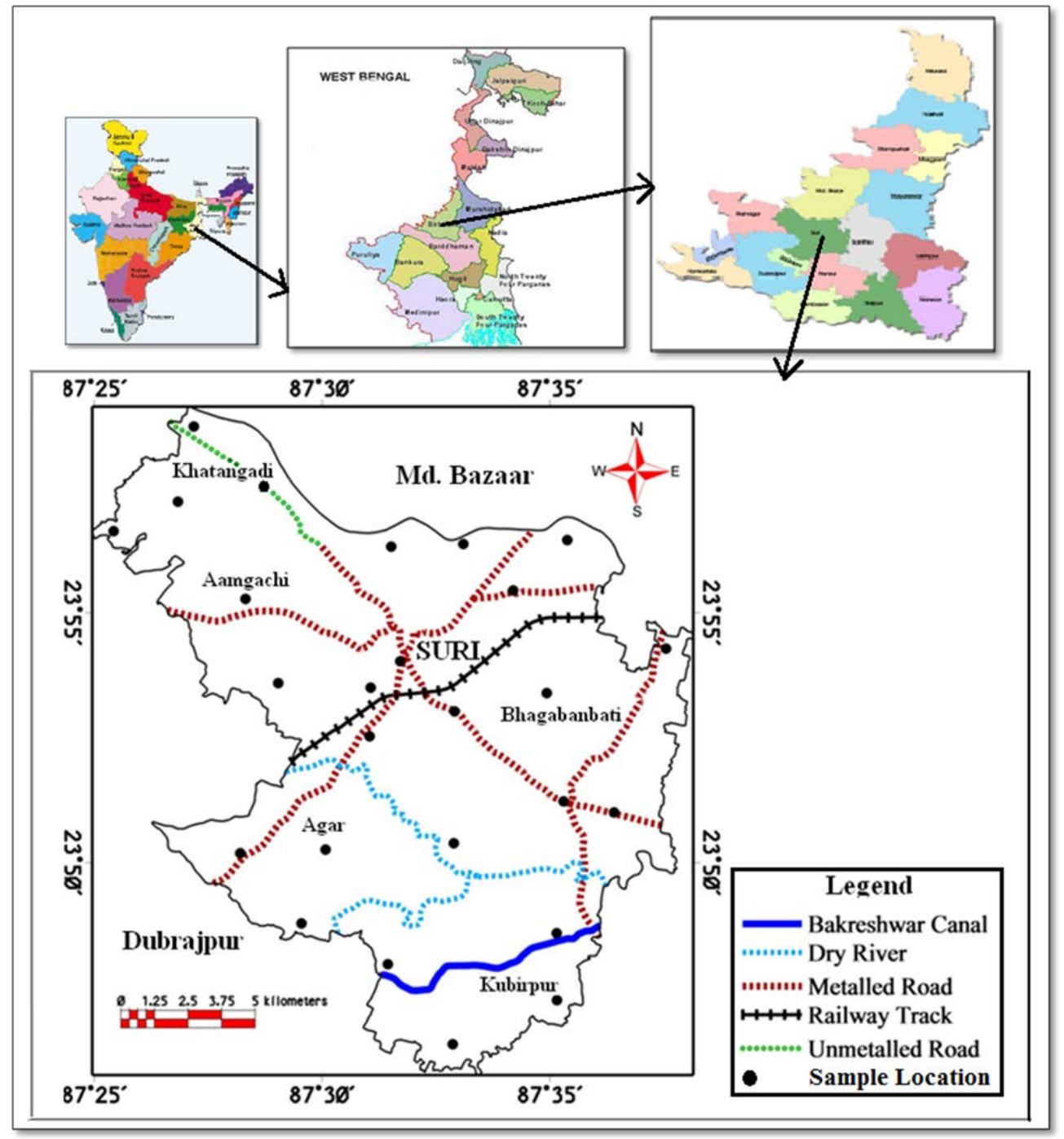

Figure 1. Map of the Study area 


\section{Study Area}

The present study has been carried out in Suri (comprising of two blocks - Suri I and Suri II), the district headquarter of Birbhum district, West Bengal, India. The blocks are located between latitudes $23.76^{\circ} \mathrm{N}-23.99^{\circ} \mathrm{N}$ and longitudes $87.42^{\circ} \mathrm{E}-87.64^{\circ} \mathrm{E}$ (Figure 1). The climate of the area is generally dry. Summer temperatures soar to a maximum of $40^{\circ} \mathrm{C}$ or above whereas in winter temperatures dip to around $10^{\circ} \mathrm{C}$. Majority of the rainfall is limited to the monsoon season from June to October and hovers around an average of $1100 \mathrm{~mm}$. The area is characterized by rural setting and major occupation of the people is agriculture. The main objective of this study is assessment of quality of the groundwater used for irrigational and drinking purposes. Water in the area is generally drawn from bore wells and dug wells, though the use of submersible pumps has seen a rise over the last few years for agricultural purposes.

The study area is largely comprised of alternating layers of sand and clay, which are soft sediments and part of the Ganga - Kosi formation. Granite - gneiss which are hard and foliated type rocks belonging to the Chotanagpur Gneissic complex constitute the north western part of the study area. Hard clays dominate specific parts of the block in the eastern parts of Suri whereas lateritic soils are scattered mainly in the upper parts of Suri (Figure 2).

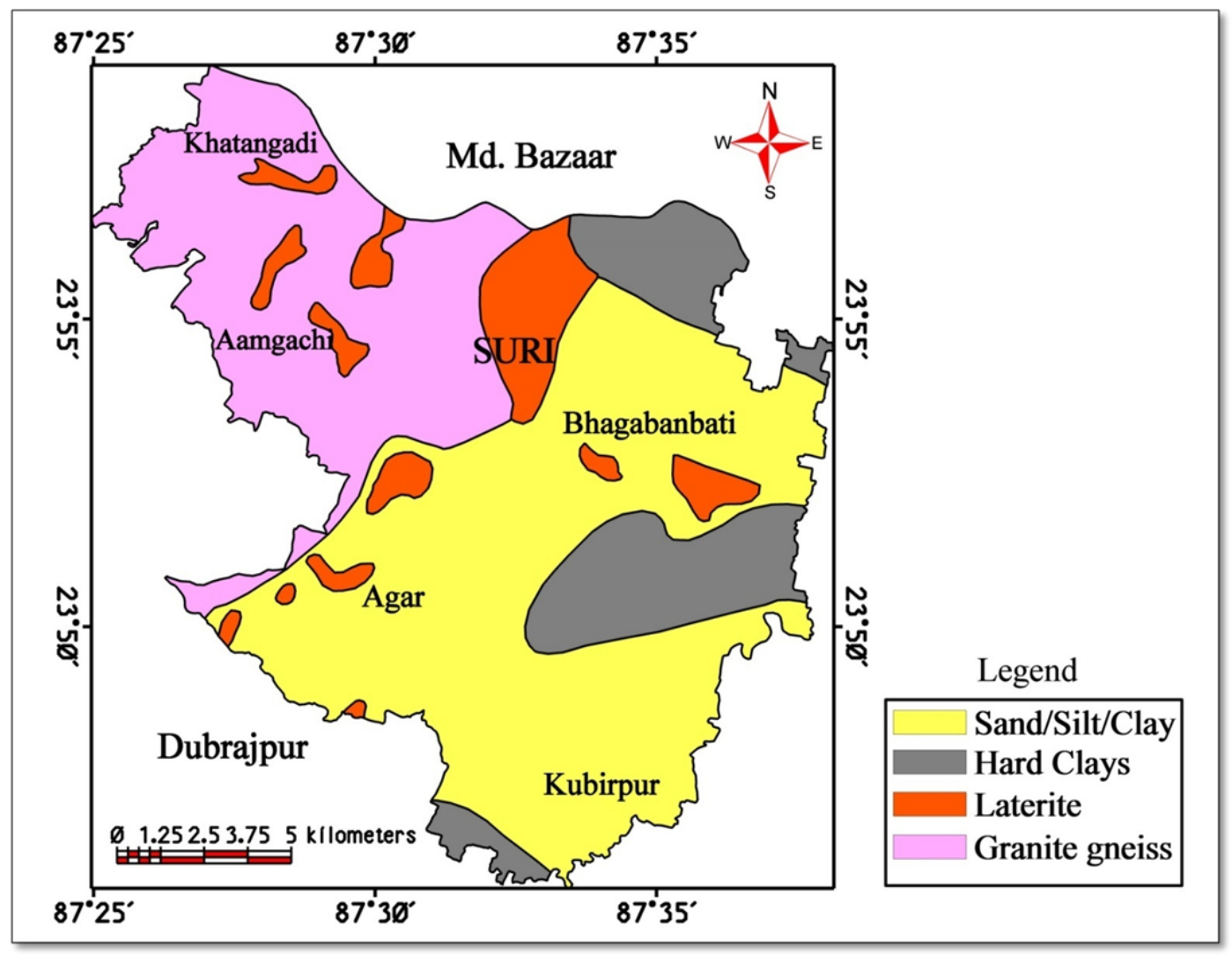

Figure 2. Map showing litho units of the study area (after GSI, 2001)

\section{Material and Method}

\subsection{Sample Collection}

A total of 26 groundwater samples were collected from bore holes ranging in depth between 2 - $21 \mathrm{~m}$ BGL covering two different seasons, post-monsoon (POM) in December 2012 and pre-monsoon (PRM) in April 2013 (Figure 1). Each sample was collected in acid-washed polyethylene $500 \mathrm{ml}$ bottle and suitable preservatives were added for storage till completion of quantitative chemical analysis. The bottle was completely filled with water taking care that no air bubble was trapped within the water sample. Then to prevent evaporation, the bottles were sealed with double plastic caps and precaution was also taken to avoid sample agitation during transfer to the laboratory. The samples were immediately transferred to the laboratory.

\subsection{Laboratory Measurements}

Samples were analyzed in the laboratory for the major ionic concentrations employing standard methods [41]. Calcium $\left(\mathrm{Ca}^{2+}\right)$ and magnesium $\left(\mathrm{Mg}^{2+}\right)$ were determined titrimetrically using standard EDTA, chloride $\left(\mathrm{Cl}^{-}\right)$by standard $\mathrm{AgNO}_{3}$ titration, bicarbonate $\left(\mathrm{HCO}_{3}{ }^{-}\right)$by titration with $\mathrm{HCl}$ and sodium $\left(\mathrm{Na}^{+}\right)$and potassium $\left(\mathrm{K}^{+}\right)$ by flame photometry. The $\mathrm{pH}, \mathrm{EC}$ (electrical conductivity) and TDS (total dissolved solids) values in samples were recorded in the field itself using pHTestr 2 and ECTestr+ by Eutech Instruments and DIST 3 by Hanna Instruments respectively. Sulfate $\left(\mathrm{SO}_{4}{ }^{2-}\right)$, phosphate $\left(\mathrm{PO}_{4}{ }^{3-}\right)$ were determined by spectrophotometer CL 22D. Nitrate $\left(\mathrm{NO}_{3}{ }^{-}\right)$, and fluoride $\left(\mathrm{F}^{-}\right)$by ion concentrations were determined using ion selective electrode. The analytical precision for ions was determined by the ionic balances calculated as $100 \times$ (cations-anions) / (cations+anions), which is generally within $\pm 5 \%$ [42]. 


\subsection{Data Treatment and Classification Methods}

The parameters such as Sodium Adsorption Ratio (SAR), Magnesium Adsorption Ratio (MAR), Soluble Sodium Percentage sodium (SSP), Residual Sodium Carbonate (RSC), Permeability Index (PI) and Kelly's ratio (KR) were calculated to evaluate the suitability of the water quality for agricultural purposes. Further the results of the analyses were interpreted using graphical representations like United States Salinity Laboratory [43] and Doneen [44] plots. Piper diagram and Water quality index calculations were used to determine drinking suitability.

\subsection{Box and Whisker Plots}

The Box and Whisker plot is a convenient way of graphically depicting groups of numerical data through their quartiles. Box plots display differences between populations without making any assumptions of the underlying statistical distribution; they are non-parametric. The spacing between the different parts of the box helps indicating the degree of dispersion and skewness in the data, and identifies outliers. Box plots can be drawn either horizontally or vertically.

The Box and Whisker Plots (Figure 3), portraying the distribution pattern of a parameter measured at more than a couple of locations, have been prepared using the minimum, maximum, quartile and median values for each parameter for both sampling sessions.

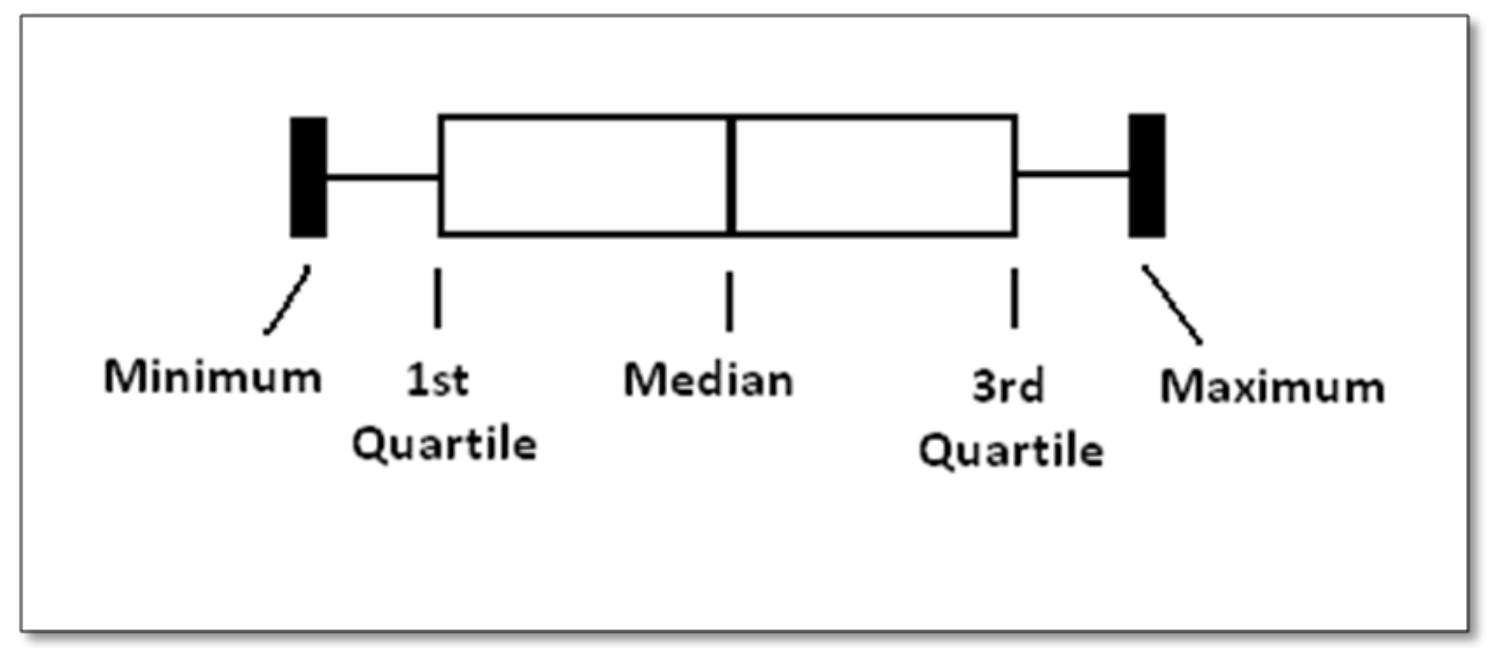

Figure 3. Box \& Whisker Plot standard

\subsection{Geospatial Analysis}

In the present study, base map showing locations of investigating points has been prepared using SoI Topo sheets $73 \mathrm{M} / 5$ and $73 \mathrm{M} / 9$ and satellite imagery (IRS-IB, LISS-II). The GIS and image processing software TNT Mips 2012 has been used to prepare the study area maps. The maps available have been scanned and imported into TNT Mips 2012 and the locations of the sampling points have been imported through point import function.

Based on the chemical analysis data this study has been categorized into two major parts:

- Assessment of water quality for irrigational purposes

- Assessment of water quality for drinking purpose.

\section{Results and Discussions}

The quantitative chemical analysis data of water samples have been presented in Table 1 and Table 2 . Overall, the groundwater in the study area is found to be alkaline and moderately hard to hard in nature. Presence of iron in water is within permissible limits baring two to four locations during both sampling sessions.

\subsection{Spatial Representation}

The simplest way of representing groundwater quality information on a map is to contour the concentrations of a particular substance of interest. Hence, an attempt has been made to infer spatial variations of crucial ions determining the quality of groundwater.

\subsection{Electrical Conductivity}

Electrical conductivity of water maybe defined as the capacity of water to conduct electrical current. This capacity is directly related to the amount of current conducting bodies (ions, radicals or solid particles). EC of water can be proportionately related to the dissolved solids in water, as the flow of current is dependent on the quantity and conducting capability of these dissolved particles.

EC is the most important parameter to demarcate salinity hazard and suitability of water for irrigation purposes. The EC varies from 90 to $300 \mu \mathrm{S} / \mathrm{cm}$ and 55 to $552 \mu \mathrm{S} / \mathrm{cm}$ during POM and PRM, respectively. Higher values were noted during PRM when compared with POM. The classification of groundwater on the basis of irrigation quality [45] shows that all samples of POM and PRM samples falls within the excellent to good limits.

The EC values for POM and PRM season are used to create the spatial distribution map for the study area (Figure 4a and Figure 4b). It is observed that conductivity values of water samples follow similar trend in both sessions.

Figure 5a and Figure 5b are the Box and Whisker plots for electrical conductivity for post monsoon and pre monsoon respectively and it is observed that in post monsoon groundwater is much less conductive than during pre monsoon. 
Table 1. Chemical Analysis Results for Post Monsoon Session (December 2012)

\begin{tabular}{|c|c|c|c|c|c|c|c|c|c|c|c|c|c|c|c|c|}
\hline Location No. & Location Name & pH & TDS & EC & TA & TH & $\mathbf{C a}^{2^{+}}$ & $\mathbf{M g}^{\mathbf{2}^{+}}$ & $\mathrm{Na}^{+}$ & $\mathrm{K}^{+}$ & $\mathrm{Fe}^{2+}$ & $\mathrm{CO}_{3}{ }^{2-}$ & $\mathrm{HCO}_{3}{ }^{-}$ & $\mathrm{Cl}^{-}$ & $\mathrm{SO}_{4}{ }^{2-}$ & $\mathrm{PO}_{4}{ }^{3-}$ \\
\hline AL1 & Abdarpur & 8.1 & 74.0 & 90.0 & 120.0 & 80.0 & 12.6 & 11.83 & 8.667 & 1.000 & 0.033 & 0.00 & 146.40 & 24.99 & 0.71 & 0.044 \\
\hline AL2 & Singur & 7.8 & 82.0 & 110.0 & 50.0 & 55.0 & 16.8 & 3.17 & 12.333 & 1.000 & 0.055 & 0.00 & 61.00 & 29.99 & 2.84 & 0.007 \\
\hline AL3 & Kochujor Primary & 7.1 & 622.0 & 190.0 & 650.0 & 365.0 & 109.2 & 22.45 & 53.333 & 3.000 & 0.000 & 0.00 & 793.00 & 129.96 & 48.76 & 0.011 \\
\hline AL4 & Lalmohanpur Primary School & 7.6 & 225.0 & 191.0 & 670.0 & 200.0 & 58.8 & 12.93 & 24.667 & 1.333 & 0.052 & 72.00 & 671.00 & 24.99 & 1.78 & 0.015 \\
\hline AL5 & Bonsonka Primary School & 7.7 & 266.0 & 200.0 & 600.0 & 240.0 & 46.2 & 30.38 & 10.000 & 1.667 & 0.030 & 0.00 & 732.00 & 15.00 & 1.15 & 0.005 \\
\hline AL6 & Talibpur High School & 7.8 & 325.0 & 210.0 & 880.0 & 250.0 & 54.6 & 27.69 & 29.333 & 4.000 & 0.070 & 0.00 & 1073.60 & 15.00 & 6.13 & 0.014 \\
\hline AL7 & Kubirpur Primary School & 8.0 & 294.0 & 220.0 & 620.0 & 200.0 & 37.8 & 25.74 & 11.667 & 4.667 & 0.039 & 48.00 & 658.80 & 34.99 & 7.64 & 0.000 \\
\hline AL8 & Abinashpur Hospital (Sultanpur) & 7.0 & 182.0 & 190.0 & 550.0 & 180.0 & 46.2 & 15.74 & 14.667 & 0.667 & 0.027 & 36.00 & 597.80 & 15.00 & 1.69 & 0.000 \\
\hline AL9 & Piasala More & 7.8 & 306.0 & 240.0 & 800.0 & 210.0 & 42.0 & 25.62 & 58.333 & 5.333 & 0.091 & 180.00 & 610.00 & 39.99 & 15.99 & 0.019 \\
\hline AL10 & Purandarpur & 7.1 & 280.0 & 210.0 & 560.0 & 290.0 & 79.8 & 22.08 & 7.000 & 1.667 & 0.055 & 0.00 & 683.20 & 79.98 & 0.80 & 0.000 \\
\hline AL11 & Gangta (Beside Mandir) & 7.4 & 247.0 & 220.0 & 670.0 & 210.0 & 46.2 & 23.06 & 41.667 & 4.333 & 0.021 & 84.00 & 646.60 & 34.99 & 6.22 & 0.007 \\
\hline AL12 & Majhigram & 7.4 & 196.0 & 200.0 & 540.0 & 200.0 & 37.8 & 25.74 & 19.667 & 1.000 & 0.018 & 12.00 & 634.40 & 15.00 & 1.51 & 0.017 \\
\hline AL13 & Bhaganbati Primary School & 7.2 & 309.0 & 240.0 & 370.0 & 280.0 & 71.4 & 24.77 & 24.000 & 1.000 & 1.809 & 0.00 & 451.40 & 34.99 & 3.64 & 0.017 \\
\hline AL14 & Dhalla & 8.4 & 250.0 & 250.0 & 790.0 & 140.0 & 21.0 & 21.35 & 56.667 & 3.000 & 0.158 & 180.00 & 597.80 & 34.99 & 0.62 & 0.007 \\
\hline AL15 & Saktipur Primary School & 7.6 & 202.0 & 190.0 & 430.0 & 200.0 & 33.6 & 28.30 & 24.667 & 0.667 & 0.009 & 0.00 & 524.60 & 24.99 & 0.43 & 0.021 \\
\hline AL16 & Ajaypur & 7.6 & 111.0 & 160.0 & 270.0 & 160.0 & 29.4 & 21.11 & 10.333 & 0.667 & 0.015 & 0.00 & 329.40 & 15.00 & 0.71 & 0.030 \\
\hline AL17 & Joka Primary School & 7.6 & 188.0 & 230.0 & 620.0 & 160.0 & 37.8 & 15.98 & 31.667 & 1.000 & 0.076 & 204.00 & 341.60 & 19.99 & 4.09 & 0.000 \\
\hline AL18 & Khatangadi & 7.6 & 203.0 & 210.0 & 380.0 & 160.0 & 42.0 & 13.42 & 18.333 & 3.000 & 0.188 & 204.00 & 48.80 & 29.99 & 2.13 & 0.000 \\
\hline AL19 & Kendulia & 7.1 & 344.0 & 300.0 & 670.0 & 260.0 & 71.4 & 19.89 & 41.667 & 10.000 & 0.012 & 156.00 & 500.20 & 64.98 & 37.93 & 0.011 \\
\hline AL20 & Lataboni Primary School & 7.2 & 355.0 & 299.0 & 420.0 & 240.0 & 54.6 & 25.25 & 46.667 & 2.667 & 0.112 & 24.00 & 463.60 & 124.96 & 39.61 & 0.005 \\
\hline AL21 & Nabagram Primary School & 7.6 & 229.0 & 240.0 & 510.0 & 200.0 & 37.8 & 25.74 & 28.000 & 1.333 & 0.021 & 0.00 & 622.20 & 29.99 & 3.46 & 0.002 \\
\hline AL22 & Aamgachi Udayan Pathsala & 7.8 & 119.0 & 170.0 & 350.0 & 120.0 & 25.2 & 13.91 & 12.333 & 2.000 & 0.018 & 0.00 & 427.00 & 19.99 & 2.31 & 0.002 \\
\hline AL23 & Gobindopur Unique Club & 7.7 & 143.0 & 190.0 & 490.0 & 140.0 & 33.6 & 13.66 & 17.333 & 2.000 & 0.079 & 36.00 & 524.60 & 39.99 & 1.87 & 0.001 \\
\hline AL24 & Agar & 7.4 & 280.0 & 270.0 & 620.0 & 280.0 & 58.8 & 32.45 & 34.000 & 1.333 & 0.012 & 60.00 & 634.40 & 29.99 & 4.09 & 0.002 \\
\hline AL25 & Ekdala More & 7.5 & 264.0 & 260.0 & 800.0 & 260.0 & 63.0 & 25.01 & 24.667 & 1.333 & 0.000 & 180.00 & 610.00 & 19.99 & 1.24 & 0.025 \\
\hline AL26 & Suri Town & 7.1 & 256.0 & 251.0 & 350.0 & 300.0 & 50.4 & 42.46 & 15.333 & 3.667 & 0.015 & 0.00 & 427.00 & 74.98 & 22.12 & 0.022 \\
\hline
\end{tabular}

Note : EC - Electrical Conductivity $(\mu \mathrm{S} / \mathrm{cm})$; TDS - Total Dissolved Solids (mg/l) ; Hardness (mg/l) ; Cl - Chloride (mg/l); $\mathrm{HCO}_{3}-\mathrm{Bi}$-Carbonate $(\mathrm{mg} / \mathrm{l})$;

$\mathrm{SO}_{4}$ - Sulfate (mg/l); Fe - Iron (mg/l); Mg - Magnesium (mg/l); Ca - Calcium (mg/l) ; Na - Sodium (mg/l)
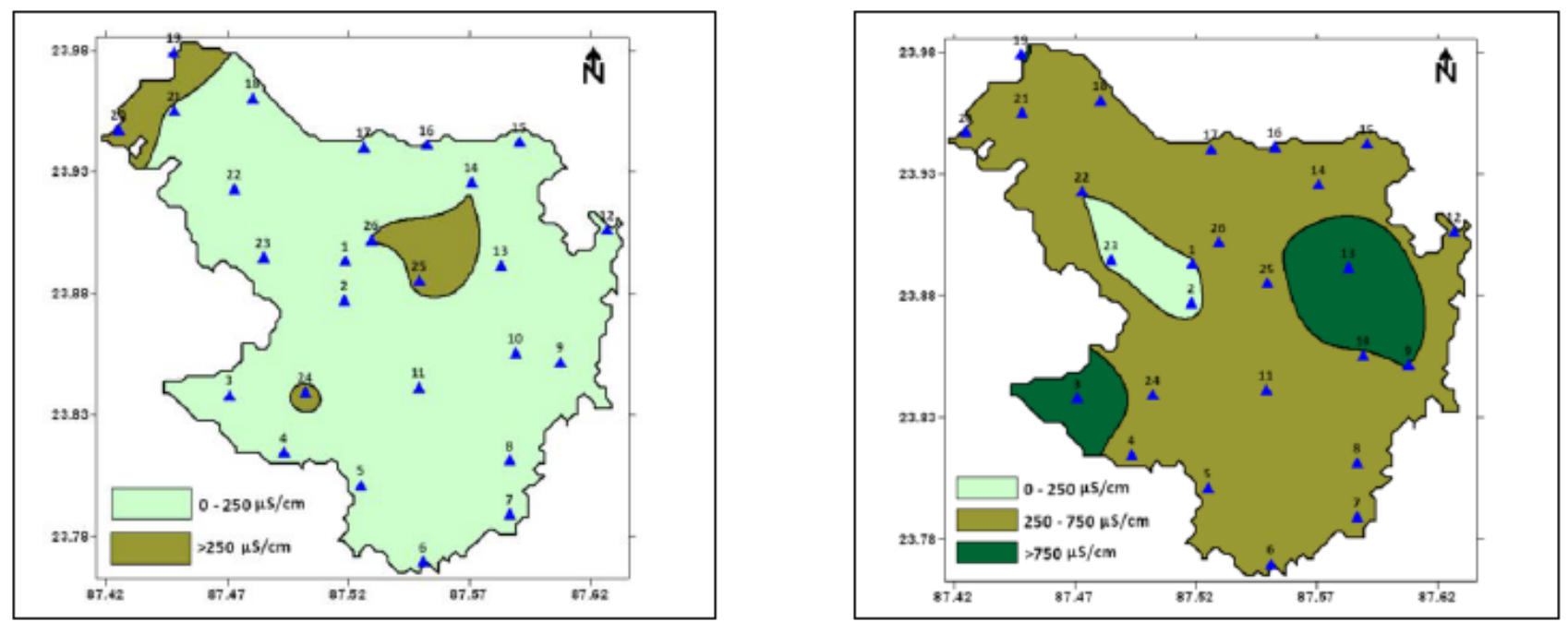

Figure 4 Spatial distribution of EC (a. Post monsoon; b. Pre monsoon)
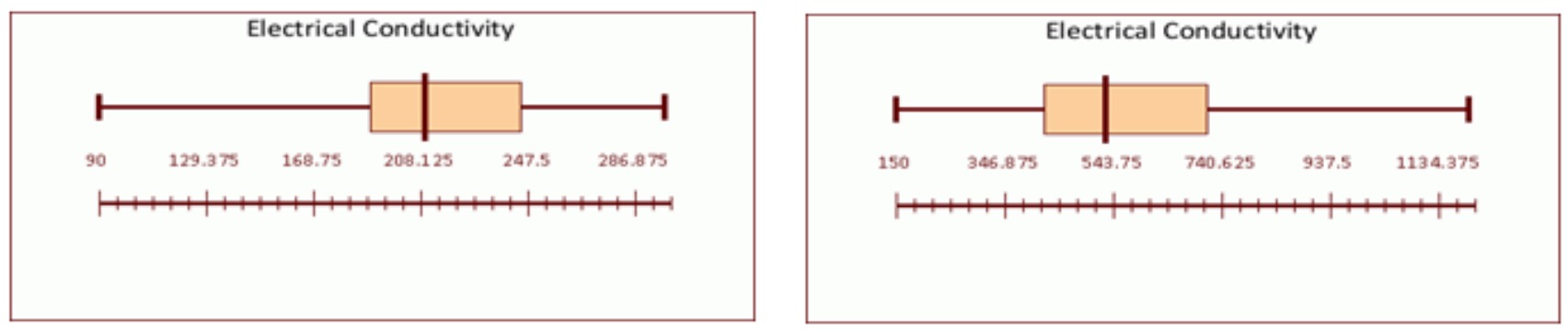

Figure 5. Box \& Whisker Plot for EC (a. Post monsoon; b. Pre monsoon) 
Table 2. Chemical Analysis Results for Pre Monsoon Session (April 2013)

\begin{tabular}{|c|c|c|c|c|c|c|c|c|c|c|c|c|c|c|c|c|}
\hline Location No. & Location Name & pH & TDS & EC & TA & TH & $\mathbf{C a}^{2+}$ & $\mathbf{M g}^{2+}$ & $\mathrm{Na}^{+}$ & $\mathbf{K}^{+}$ & $\mathbf{F e}^{2+}$ & $\mathrm{CO}_{3}{ }^{2-}$ & $\mathrm{HCO}_{3}^{-}$ & $\mathrm{Cl}^{-}$ & $\mathrm{SO}_{4}{ }^{{ }^{-}}$ & $\mathrm{PO}_{4}{ }^{3-}$ \\
\hline AL1 & Abdarpur & 8.4 & 150.0 & 55.0 & 40.0 & 48.0 & 6.7 & 7.6 & 9.0 & 0.2 & 0.01 & 0.0 & 48.8 & 15.0 & 0.5 & 0.64 \\
\hline AL2 & Singur & 7.3 & 180.0 & 83.0 & 60.0 & 72.0 & 15.1 & 8.3 & 14.0 & 0.28 & 0.04 & 0.0 & 73.2 & 30.0 & 2.8 & 0.52 \\
\hline AL3 & Kochujor Primary School & 6.6 & 1200.0 & 590.0 & 140.0 & 244.0 & 57.1 & 24.7 & 66.0 & 0.76 & 0.01 & 0.0 & 170.8 & 179.9 & 45.7 & 0.03 \\
\hline AL4 & Lalmohanpur Primary School & 7.3 & 510.0 & 227.0 & 180.0 & 124.0 & 23.5 & 15.9 & 28.0 & 0.32 & 0.16 & 12.0 & 195.2 & 15.0 & 1.9 & 0.18 \\
\hline AL5 & Bonsonka Primary School & 7.4 & 600.0 & 277.0 & 190.0 & 180.0 & 20.2 & 31.6 & 13.0 & 0.32 & 0.00 & 12.0 & 207.4 & 25.0 & 1.4 & 0.09 \\
\hline AL6 & Talibpur High School & 7.2 & 720.0 & 333.0 & 230.0 & 160.0 & 16.8 & 28.8 & 40.0 & 1.08 & 0.15 & 0.0 & 280.6 & 15.0 & 6.6 & 0.46 \\
\hline AL7 & Kubirpur Primary School & 7.4 & 690.0 & 309.0 & 240.0 & 152.0 & 18.5 & 25.8 & 51.0 & 1.28 & 0.20 & 0.0 & 292.8 & 40.0 & 10.4 & 0.03 \\
\hline AL8 & Abinashpur Hospital (Sultanpur) & 7.1 & 420.0 & 182.0 & 180.0 & 156.0 & 33.6 & 17.6 & 18.0 & 0.24 & 0.20 & 12.0 & 195.2 & 20.0 & 1.2 & 0.49 \\
\hline AL9 & Piasala More & 7.4 & 750.0 & 317.0 & 240.0 & 132.0 & 18.5 & 20.9 & 64.0 & 1.32 & 0.11 & 0.0 & 292.8 & 35.0 & 15.6 & 0.09 \\
\hline AL10 & Purandarpur & 7.1 & 710.0 & 316.0 & 140.0 & 208.0 & 38.6 & 27.2 & 8.0 & 0.36 & 0.10 & 0.0 & 170.8 & 75.0 & 0.6 & 0.0 \\
\hline AL11 & Gangta (Beside Mandir) & 7.0 & 580.0 & 256.0 & 250.0 & 180.0 & 45.4 & 16.3 & 44.0 & 1.2 & 0.05 & 36.0 & 231.8 & 35.0 & 4.3 & 0.06 \\
\hline AL12 & Majhigram & 6.9 & 470.0 & 203.0 & 160.0 & 140.0 & 20.2 & 21.9 & 19.0 & 0.24 & 0.16 & 12.0 & 170.8 & 15.0 & 0.7 & 0.12 \\
\hline AL13 & Bhaganbati Primary School & 6.6 & 1150.0 & 552.0 & 120.0 & 384.0 & 95.8 & 35.3 & 37.0 & 0.28 & 6.06 & 0.0 & 146.4 & 274.9 & 8.0 & 0.15 \\
\hline AL14 & Dhalla & 7.5 & 550.0 & 248.0 & 250.0 & 76.0 & 11.8 & 11.4 & 69.0 & 0.8 & 0.27 & 24.0 & 256.2 & 20.0 & 1.1 & 0.03 \\
\hline AL15 & Saktipur Primary School & 6.8 & 420.0 & 148.0 & 150.0 & 124.0 & 30.2 & 11.8 & 23.0 & 0.2 & 2.01 & 24.0 & 134.2 & 25.0 & 2.1 & 0.0 \\
\hline AL16 & Ajaypur & 7.6 & 280.0 & 115.0 & 130.0 & 104.0 & 28.6 & 8.0 & 13.0 & 0.32 & 0.06 & 0.0 & 158.6 & 20.0 & 0.1 & 0.06 \\
\hline AL17 & Joka Primary School & 6.9 & 420.0 & 194.0 & 180.0 & 96.0 & 21.8 & 10.1 & 33.0 & 0.2 & 0.25 & 12.0 & 195.2 & 15.0 & 2.5 & 0.03 \\
\hline AL18 & Khatangadi & 7.8 & 420.0 & 181.0 & 130.0 & 140.0 & 28.6 & 16.7 & 22.0 & 0.72 & 0.26 & 12.0 & 134.2 & 40.0 & 6.7 & 0.0 \\
\hline AL19 & Kendulia & 6.4 & 790.0 & 353.0 & 140.0 & 184.0 & 45.4 & 17.2 & 48.0 & 2.48 & 0.50 & 0.0 & 170.8 & 105.0 & 41.4 & 0.0 \\
\hline AL20 & Lataboni Primary School & 6.7 & 480.0 & 219.0 & 130.0 & 160.0 & 33.6 & 18.5 & 21.0 & 0.36 & 0.63 & 0.0 & 158.6 & 50.0 & 5.7 & 0.06 \\
\hline AL21 & Nabagram Primary School & 7.0 & 510.0 & 224.0 & 150.0 & 108.0 & 20.2 & 14.1 & 31.0 & 0.28 & 0.06 & 0.0 & 183.0 & 30.0 & 2.0 & 0.0 \\
\hline AL22 & Aamgachi Udayan Pathsala & 6.9 & 250.0 & 113.0 & 100.0 & 92.0 & 23.5 & 8.1 & 12.0 & 0.24 & 0.18 & 0.0 & 122.0 & 25.0 & 2.1 & 0.03 \\
\hline AL23 & Gobindopur Unique Club & 7.6 & 230.0 & 102.0 & 60.0 & 80.0 & 16.8 & 9.3 & 16.0 & 0.16 & 0.25 & 0.0 & 73.2 & 35.0 & 1.8 & 0.03 \\
\hline AL24 & Agar & 6.9 & 650.0 & 286.0 & 90.0 & 120.0 & 16.8 & 19.0 & 38.0 & 0.36 & 0.01 & 0.0 & 109.8 & 30.0 & 3.5 & 0.12 \\
\hline AL25 & Ekdala More & 7.1 & 600.0 & 270.0 & 320.0 & 152.0 & 21.8 & 23.8 & 31.0 & 0.28 & 0.28 & 0.0 & 390.4 & 20.0 & 1.5 & 0.18 \\
\hline AL26 & Suri Town & 6.8 & 730.0 & 322.0 & 130.0 & 240.0 & 52.1 & 26.8 & 25.0 & 1.12 & 0.11 & 0.0 & 158.6 & 85.0 & 56.7 & 4.76 \\
\hline
\end{tabular}

Note : EC - Electrical Conductivity ( $\mu \mathrm{S} / \mathrm{cm})$; TDS - Total Dissolved Solids (mg/l) ; Hardness (mg/l) ; Cl - Chloride (mg/l); $\mathrm{HCO}_{3}-\mathrm{Bi}_{-} \mathrm{Carbonate}$ $(\mathrm{mg} / \mathrm{l})$;

$\mathrm{SO}_{4}$ - Sulfate (mg/l) ; Fe - Iron (mg/l) ; Mg - Magnesium (mg/l) ; Ca - Calcium (mg/l) ; Na - Sodium (mg/l)

\subsection{Total Dissolved Solids (TDS)}

Total Dissolved Solids (TDS) is a measure of the combined content of all inorganic and organic substances present in a liquid in molecular, ionized or micro-granular (colloidal) suspended form. This parameter is generally used as a manifestation of aesthetic characteristics of

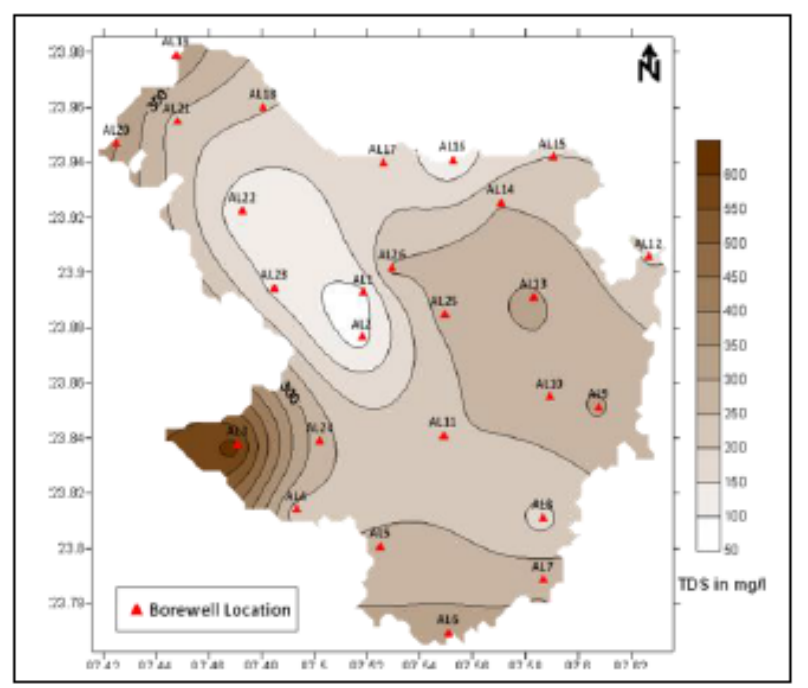

drinking water. High TDS levels generally indicate hard water and can thus affect the taste of water.

Figure $6 \mathrm{a}$ and Figure $6 \mathrm{~b}$ present the spatial distribution maps of TDS in the study area for both sessions and TDS values of water samples also follow similar trends in both sessions. During pre monsoon eastern parts of the study area have more dissolved solids in groundwater compared to post monsoon.

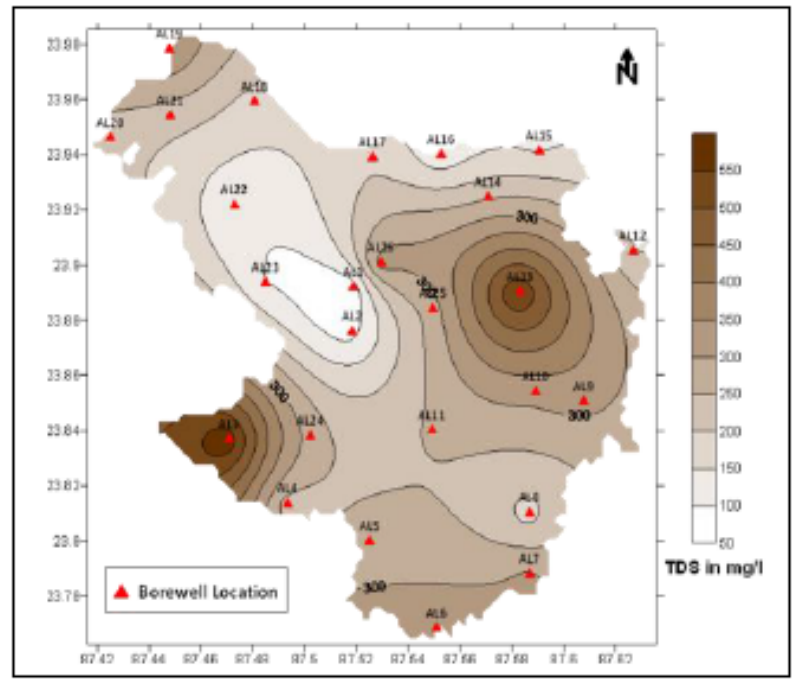

Figure 6. Spatial distribution of TDS (a. Post monsoon; b. Pre monsoon)

Figure 7a and Figure 7b below are the Box and Whisker plots for total dissolved solids for post monsoon and pre monsoon respectively. TDS values during both post and pre monsoon are in the same range. 

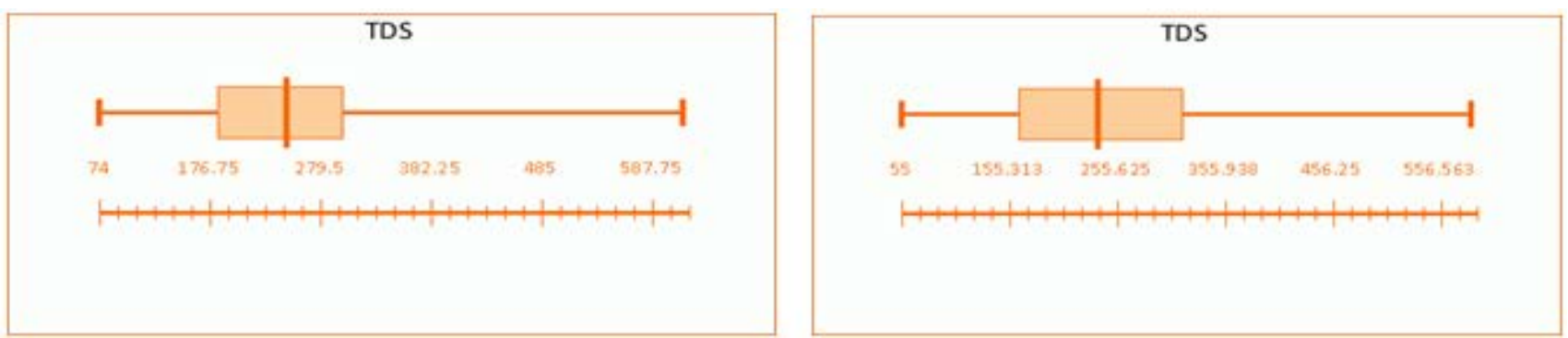

Figure 7. Box \& Whisker Plot for TDS (a. Post monsoon; b. Pre monsoon)

\subsection{Sodium $\left(\mathrm{Na}^{+}\right)$}

Sodium toxicity is recorded as a result of high sodium in water as $\mathrm{Na} \%$ and SAR ratios. Typical toxicity symptoms to plants and trees are leaf burn and dead tissue along the outside edges of leaves. Symptoms appear first on the older leaves, starting at the outer edges and when the severity increases it moves progressively inward between the veins toward the leaf centre. The adverse effect of sodium on the soil is more closely related to the ratio of sodium to the total cations in the irrigation water than to the absolute concentration of sodium. It has now

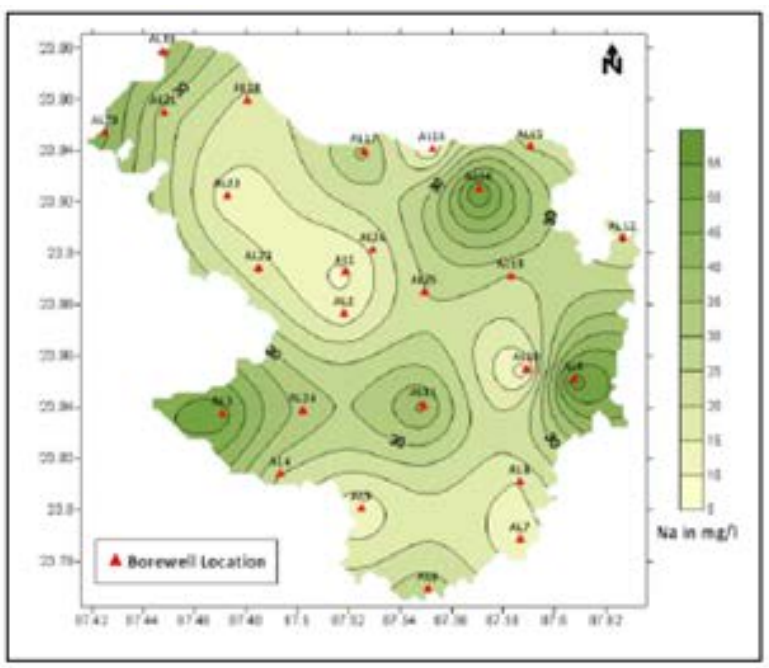

been recognized that as percent of sodium increases in the soil solution larger quantities are absorbed during the exchange, replacing calcium and magnesium, thus resulting in alkali soil. The concentration of sodium in the water samples collected vary from 7.00 to $58.3 \mathrm{mg} / \mathrm{L}$ (post-monsoon) and 8.00 to $69.0 \mathrm{mg} / \mathrm{L}$ (pre-monsoon) (Table 1 and Table 2). Figure 8a and Figure 8b represent the spatial distribution of $\mathrm{Na}$ in the study area and it is found that in both the seasons all samples are within the safe category (i.e., $<200 \mathrm{mg} / \mathrm{L}$ ). The source of $\mathrm{Na}^{+}$into the groundwater has been attributed to the weathering of feldspar and due to over exploitation of groundwater [46].

Figure 8. Spatial distribution of Na (a. Post monsoon; b. Pre monsoon)

Figure 9a and Figure 9b below are the Box and Whisker plots for sodium $\left(\mathrm{Na}^{+}\right)$for post monsoon and pre monsoon respectively. Sodium values for both all samples in different sampling sessions are in a similar range.
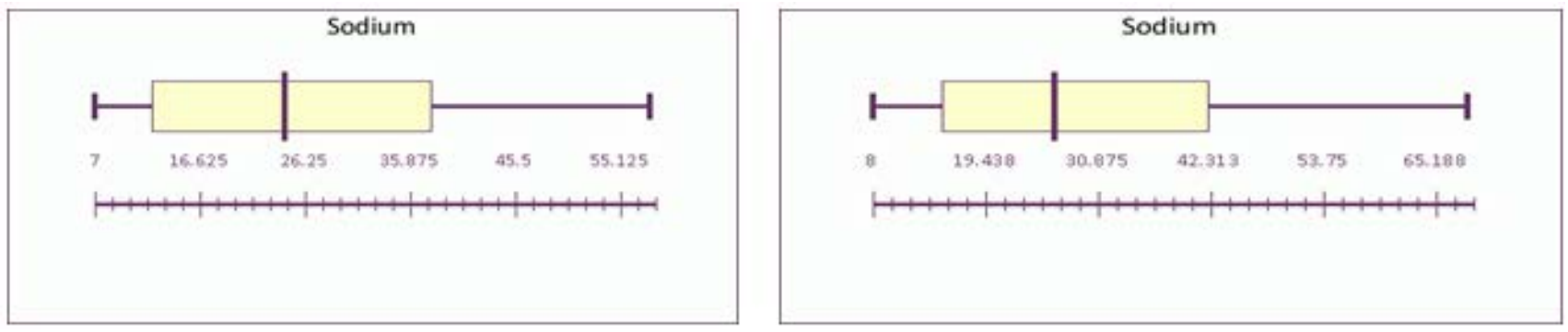

Figure 9. Box \& Whisker Plot for $\mathrm{Na}^{+}$(a. Post monsoon; b. Pre monsoon)

\subsection{Chloride ( $\left.\mathrm{Cl}^{-}\right)$}

Chloride is the most common toxicity in water used for irrigation purpose. It is neither adsorbed nor held back by soils; rather it moves readily with the soil-water and gets adsorbed by crops, and accumulates in the leaves [47].
Higher intake of $\mathrm{Cl}^{-}$beyond the crop tolerance limit in plants develops symptoms like leaf burn and drying of leaf tissues. Excessive necrosis (dead tissue) is often accompanied by early leaf drop or defoliation [48]. The permissible limit of $\mathrm{Cl}^{-}$in groundwater is $600 \mathrm{mg} / \mathrm{L}$ [45]. Too much of chloride leads to bad taste in water and also 
chloride ion combines with the $\mathrm{Na}$ (that is being derived from the weathering of granitic terrains) and forms $\mathrm{NaCl}$, whose excess presence in water makes it saline and unfit for drinking and irrigation purposes. The concentration of chloride in the water samples collected vary from 15.00 to $129.96 \mathrm{mg} / \mathrm{L}$ (post-monsoon) and 15.00 to $274.9 \mathrm{mg} / \mathrm{L}$ (pre-monsoon) (Table 1 and Table 2). The maximum chloride content in water during pre monsoon is almost found to be double than that in post monsoon. Figure 10a and Figure 10b present the spatial distribution maps of chloride in the study area for both sessions. In the post monsoon session highest chloride content in water is observed in the western parts of the study area whereas in pre monsoon the highest values of chloride are reported in the eastern parts of the study area.
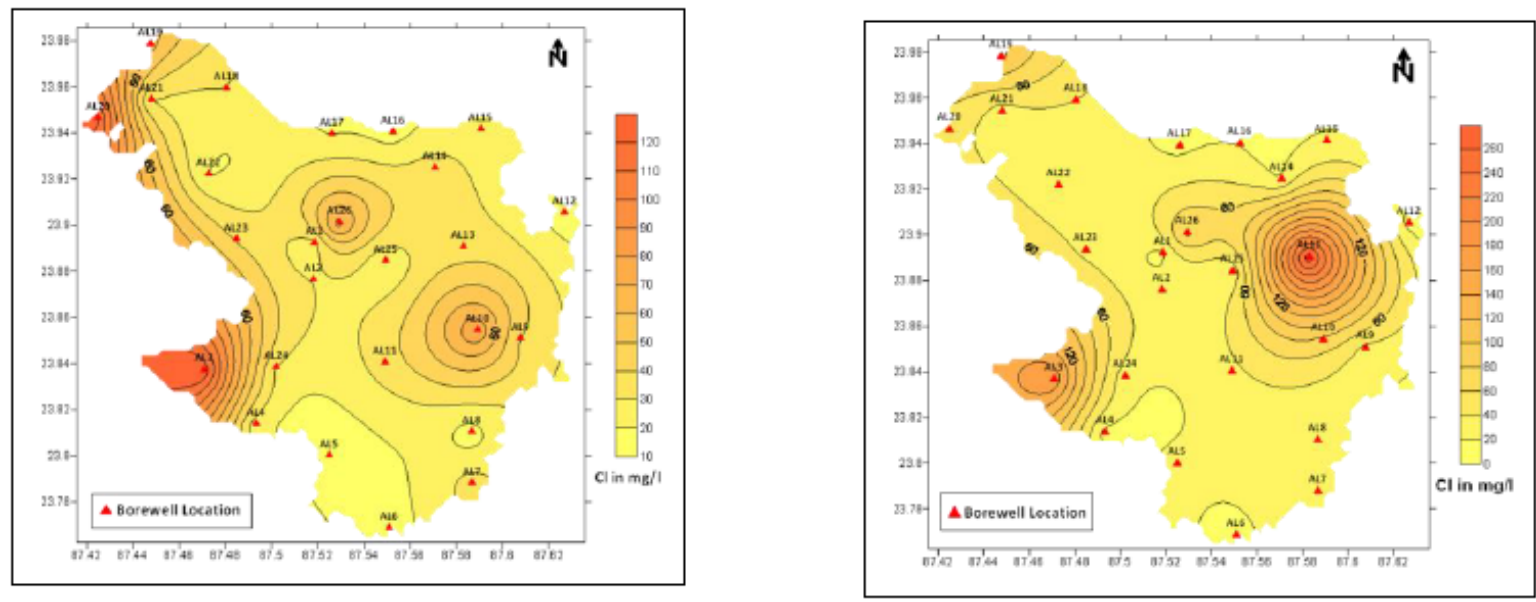

Figure 10. Spatial distribution of $\mathrm{Cl}$ (a. Post monsoon; b. Pre monsoon)

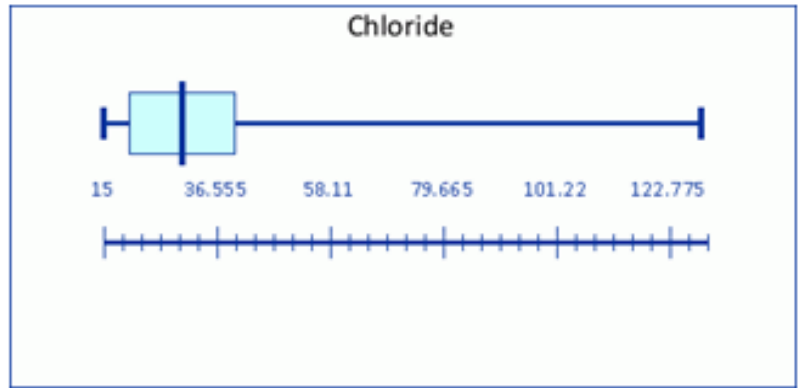

Figure 11. Box \& Whisker Plot for $\mathrm{Cl}^{-}$

Figure 11a and Figure 11b below are the Box and Whisker plots for chloride $\left(\mathrm{Cl}^{-}\right)$for post monsoon and pre monsoon respectively.

\subsection{Sulfate $\left(\mathrm{SO}_{4}{ }^{2-}\right)$}

The sulfate ion causes no particular harmful effects on soils or plants; however, it contributes to increase in

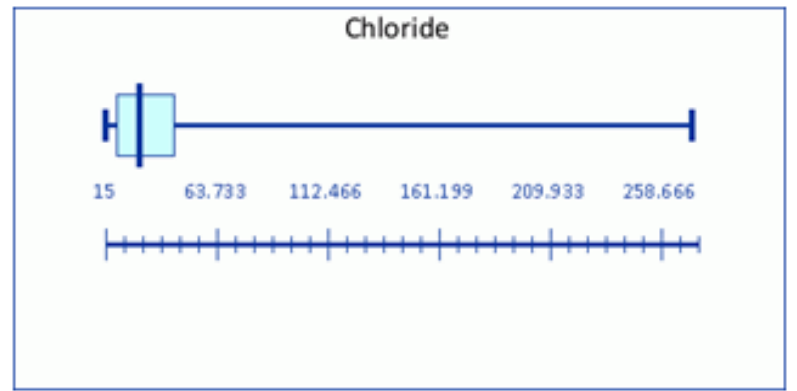

(a. Post monsoon; b. Pre monsoon)

salinity of the soil solution. Sulphur is an essential element in plant nutrition and in the form of sulfate it is readily available to plants. The spatial distribution maps of sulfate in the study area for both sessions are shown in Figure 12a and Figure 12b. Sulfate ion varied from 0.43 to $48.8 \mathrm{mg} / \mathrm{L}$ during the post-monsoon and from 0.1 to 56.7 $\mathrm{mg} / \mathrm{L}$ in pre-monsoon seasons.
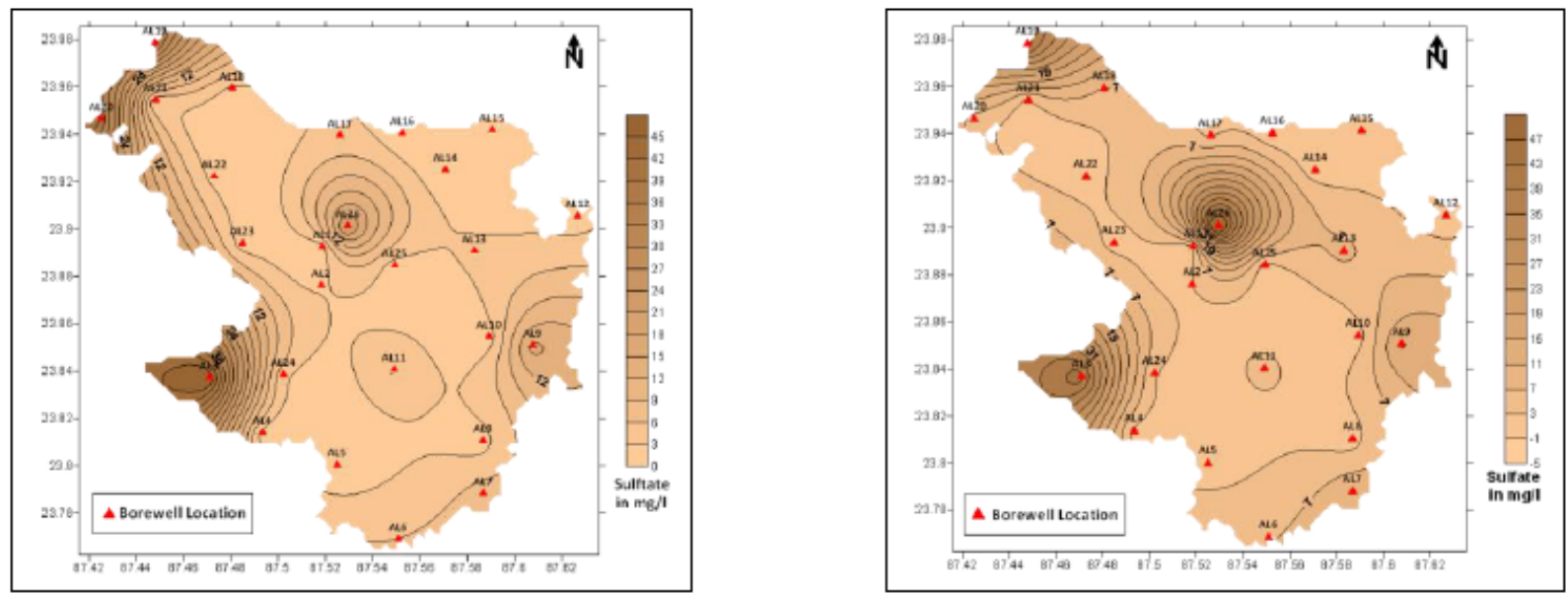

Figure 12. Spatial distribution of $\mathrm{SO}_{4}$ (a. Post monsoon; b. Pre monsoon) 

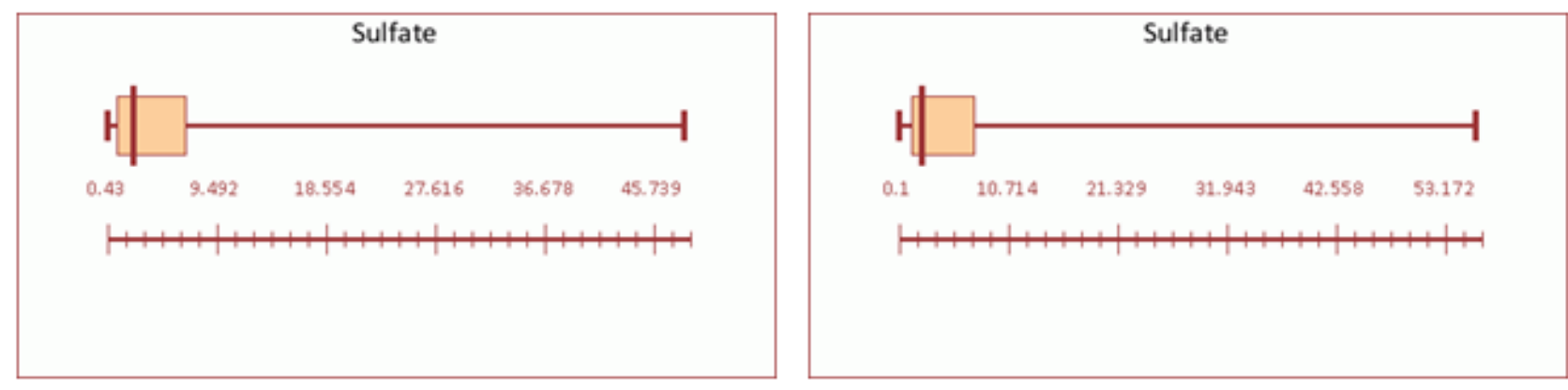

Figure 13. Box \& Whisker Plot for $\mathrm{SO}_{4}{ }^{2-}$ (a. Post monsoon; b. Pre monsoon)

Figure 13a and Figure 13b below are the Box and Whisker plots for sulfate $\left(\mathrm{SO}_{4}{ }^{2-}\right)$ for post monsoon and pre monsoon respectively. In case of sulfate ion, the range of concentration in water and the average concentration both follow similar patterns during both sampling sessions.

\subsection{Water Quality for Irrigation Purposes}

To assess the overall irrigational water quality of the samples collected, six computed water quality parameters have been considered; namely - Sodium Adsorption Ratio (SAR), Soluble Sodium Percentage (SSP), Permeability Index (P.I.), Residual Sodium Carbonate (RSC), Magnesium Adsorption Ratio and Kelly's Ratio. Their corresponding values have been presented in Table 3.

Table 3. Values of Computed Water Quality Parameters / Indices for Post Monsoon and Pre Monsoon Sessions

\begin{tabular}{|c|c|c|c|c|c|c|c|c|c|c|c|c|c|}
\hline \multirow{2}{*}{$\begin{array}{l}\text { Location } \\
\text { No. }\end{array}$} & \multirow{2}{*}{$\begin{array}{l}\text { Location } \\
\text { Name }\end{array}$} & \multicolumn{2}{|c|}{ SAR } & \multicolumn{2}{|c|}{ SSP } & \multicolumn{2}{|c|}{ P.I. } & \multicolumn{2}{|c|}{ RSC } & \multicolumn{2}{|c|}{ MAR } & \multicolumn{2}{|c|}{$\mathbf{K R}$} \\
\hline & & \begin{tabular}{|c|} 
Post \\
Monsoon \\
\end{tabular} & \begin{tabular}{|c|} 
Pre \\
Monsoon \\
\end{tabular} & \begin{tabular}{|c|} 
Post \\
Monsoon \\
\end{tabular} & \begin{tabular}{|c|} 
Pre \\
Monsoon \\
\end{tabular} & \begin{tabular}{|c|} 
Post \\
Monsoon \\
\end{tabular} & \begin{tabular}{|c|} 
Pre \\
Monsoon \\
\end{tabular} & \begin{tabular}{|c|} 
Post \\
Monsoon
\end{tabular} & \begin{tabular}{|c|} 
Pre \\
Monsoon \\
\end{tabular} & \begin{tabular}{|c|} 
Post \\
Monsoon
\end{tabular} & \begin{tabular}{|c|}
$\begin{array}{c}\text { Pre } \\
\text { Monsoon }\end{array}$ \\
\end{tabular} & \begin{tabular}{|c|} 
Post \\
Monsoon \\
\end{tabular} & \begin{tabular}{|c|} 
Pre \\
Monsoon
\end{tabular} \\
\hline AL1 & Abdarpur & 0.42 & 0.56 & 78.12 & 29.01 & 61.01 & 66.09 & 0.56 & 0.46 & 66.09 & 65.37 & 0.23 & 0.40 \\
\hline AL2 & Singur & 0.72 & 0.71 & 61.50 & 29.80 & 23.92 & 53.79 & 0.71 & 0.44 & 53.79 & 47.90 & 0.49 & 0.42 \\
\hline AL3 & $\begin{array}{c}\text { Kochujor } \\
\text { Primary School }\end{array}$ & 1.21 & 1.83 & 39.68 & 37.03 & 25.52 & 24.37 & 1.83 & -0.06 & 24.37 & 41.87 & 0.32 & 0.58 \\
\hline AL4 & \begin{tabular}{|c|} 
Lalmohanpur \\
Primary School \\
\end{tabular} & 0.76 & 1.09 & 66.23 & 32.88 & 26.82 & 49.31 & 1.09 & 2.02 & 49.31 & 52.99 & 0.27 & 0.49 \\
\hline AL5 & \begin{tabular}{|c|} 
Bonsonka \\
Primary School \\
\end{tabular} & 0.28 & 0.42 & 66.09 & 13.60 & 52.29 & 44.38 & 0.42 & 2.39 & 44.38 & 72.33 & 0.09 & 0.16 \\
\hline AL6 & \begin{tabular}{|c|} 
Talibpur High \\
School
\end{tabular} & 0.80 & 1.37 & 67.73 & 35.29 & 45.81 & 44.82 & 1.37 & 3.76 & 44.82 & 74.07 & 0.25 & 0.54 \\
\hline AL7 & \begin{tabular}{|c|} 
Kubirpur \\
Primary School \\
\end{tabular} & 0.36 & 1.79 & 72.86 & 42.25 & 53.16 & 43.61 & 1.79 & 3.88 & 43.61 & 69.96 & 0.13 & 0.72 \\
\hline AL8 & \begin{tabular}{|c|} 
Abinashpur \\
Hospital \\
(Sultanpur) \\
\end{tabular} & 0.47 & 0.62 & 74.13 & 20.06 & 36.22 & 46.34 & 0.62 & 1.52 & 46.34 & 46.57 & 0.18 & 0.25 \\
\hline AL9 & Piasala More & 1.74 & 2.41 & 49.24 & 51.34 & 50.41 & 42.97 & 2.41 & 3.88 & 42.97 & 65.38 & 0.60 & 1.04 \\
\hline AL10 & Purandarpur & 0.18 & 0.24 & 54.86 & 7.84 & 31.56 & 37.17 & 0.24 & 0.87 & 37.17 & 53.97 & 0.05 & 0.08 \\
\hline AL11 & \begin{tabular}{|c|} 
Gangta (Beside \\
Mandir)
\end{tabular} & 1.25 & 1.42 & 55.69 & 34.92 & 45.41 & 37.13 & 1.42 & 1.53 & 37.13 & 37.39 & 0.43 & 0.53 \\
\hline AL12 & Majhigram & 0.60 & 0.69 & 66.80 & 22.73 & 53.16 & 46.60 & 0.69 & 1.79 & 46.60 & 64.38 & 0.21 & 0.29 \\
\hline AL13 & \begin{tabular}{|c|} 
Bhaganbati \\
Primary School \\
\end{tabular} & 0.62 & 0.82 & 41.78 & 17.29 & 36.64 & 18.20 & 0.82 & -2.39 & 18.20 & 38.04 & 0.19 & 0.21 \\
\hline AL14 & Dhalla & 2.07 & 3.42 & 61.61 & 66.30 & 62.89 & 48.19 & 3.42 & 3.61 & 48.19 & 61.71 & 0.87 & 1.95 \\
\hline AL15 & $\begin{array}{c}\text { Saktipur } \\
\text { Primary School } \\
\end{array}$ & 0.75 & 0.90 & 58.45 & 28.71 & 58.40 & 43.42 & 0.90 & 0.69 & 43.42 & 39.43 & 0.27 & 0.40 \\
\hline AL16 & Ajaypur & 0.35 & 0.55 & 63.62 & 21.53 & 54.48 & 61.28 & 0.55 & 1.17 & 61.28 & 31.69 & 0.14 & 0.27 \\
\hline AL17 & $\begin{array}{c}\text { Joka Primary } \\
\text { School } \\
\end{array}$ & 1.08 & 1.46 & 52.84 & 42.68 & 41.33 & 54.54 & 1.46 & 2.11 & 54.54 & 43.53 & 0.43 & 0.74 \\
\hline AL18 & Khatangadi & 0.63 & 0.81 & 23.07 & 25.67 & 34.75 & 40.20 & 0.81 & 0.77 & 40.20 & 49.42 & 0.25 & 0.34 \\
\hline AL19 & Kendulia & 1.12 & 1.53 & 42.49 & 36.73 & 31.71 & 30.98 & 1.53 & 0.53 & 30.98 & 38.77 & 0.35 & 0.56 \\
\hline AL20 & $\begin{array}{c}\text { Lataboni } \\
\text { Primary School }\end{array}$ & 1.31 & 0.72 & 42.20 & 22.24 & 43.53 & 39.88 & 0.72 & 0.92 & 39.88 & 47.91 & 0.42 & 0.28 \\
\hline AL21 & \begin{tabular}{|c|} 
Nabagram \\
Primary School \\
\end{tabular} & 0.86 & 1.29 & 62.02 & 38.34 & 53.16 & 50.46 & 1.29 & 1.99 & 50.46 & 53.74 & 0.30 & 0.62 \\
\hline AL22 & \begin{tabular}{|c|} 
Aamgachi \\
Udayan \\
Pathsala \\
\end{tabular} & 0.49 & 0.54 & 90.06 & 22.19 & 47.92 & 60.12 & 0.54 & 0.82 & 60.12 & 36.47 & 0.22 & 0.28 \\
\hline AL23 & $\begin{array}{c}\text { Gobindopur } \\
\text { Unique Club } \\
\end{array}$ & 0.63 & 0.77 & 82.85 & 30.26 & 40.39 & 48.16 & 0.77 & 0.36 & 48.16 & 47.91 & 0.27 & 0.43 \\
\hline AL24 & Agar & 0.88 & 1.50 & 46.76 & 40.65 & 47.91 & 34.55 & 1.50 & 0.96 & 34.55 & 65.37 & 0.26 & 0.68 \\
\hline AL25 & Ekdala More & 0.66 & 1.09 & 51.21 & 30.60 & 39.82 & 58.58 & 1.09 & 5.31 & 58.58 & 64.46 & 0.20 & 0.44 \\
\hline AL26 & Suri Town & 0.38 & 0.70 & 40.01 & 18.74 & 58.40 & 28.31 & 0.70 & 0.00 & 28.31 & 46.16 & 0.11 & 0.22 \\
\hline
\end{tabular}




\subsubsection{Sodium Adsorption Ratio (SAR)}

Sodium adsorption ratio is a measure of the sodicity of the soil determined through quantitative chemical analysis of water in contact with it. An excess of $\mathrm{HCO}_{3}{ }^{-}$and $\mathrm{CO}_{3}{ }^{2-}$ ions in water react with $\mathrm{Na}^{+}$in soil, resulting in a sodium hazard [8]. SAR values are plotted against EC values (in $\mu \mathrm{mhos} / \mathrm{cm}$ ) over the U.S. Salinity diagram to categorize analyzed water samples according to their irrigational

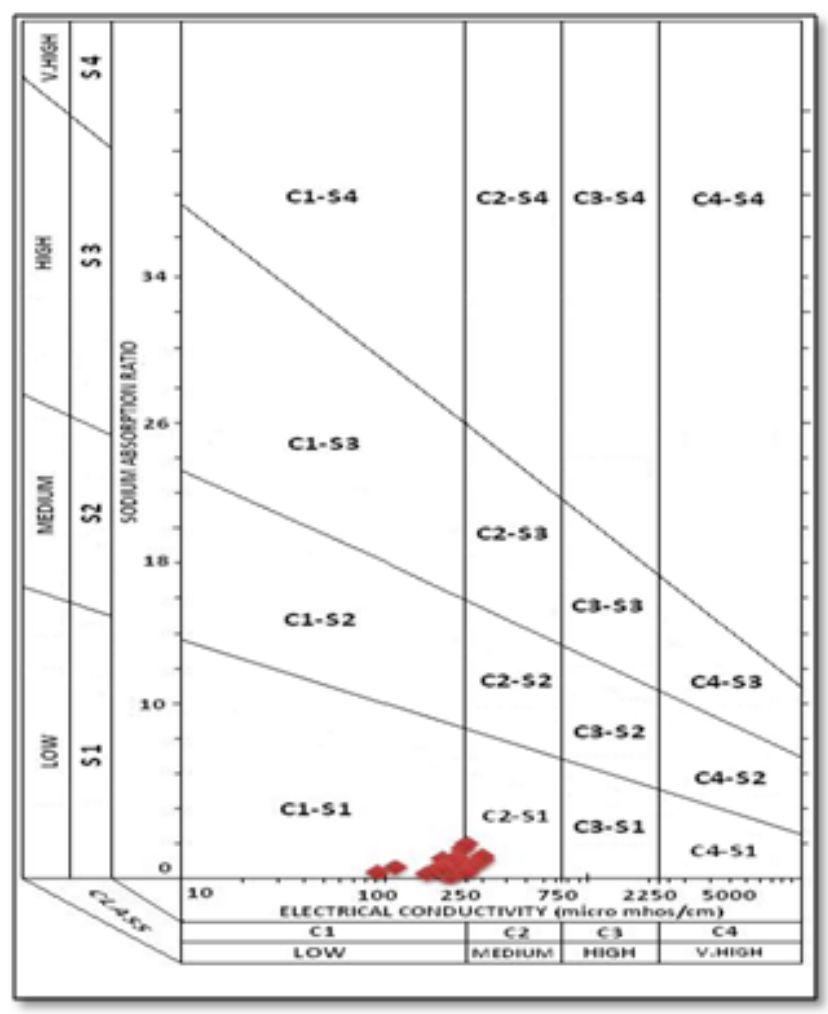

Figure 14. U.S. Salinity Diagram (a. Post monsoon; b. Pre monsoon)

In the present study the SAR values range from 0.18 2.07 in post monsoon and $0.24-3.24$ during pre monsoon. Based on the SAR values all samples have low sodium hazard and on plotting over the U.S. Salinity diagram

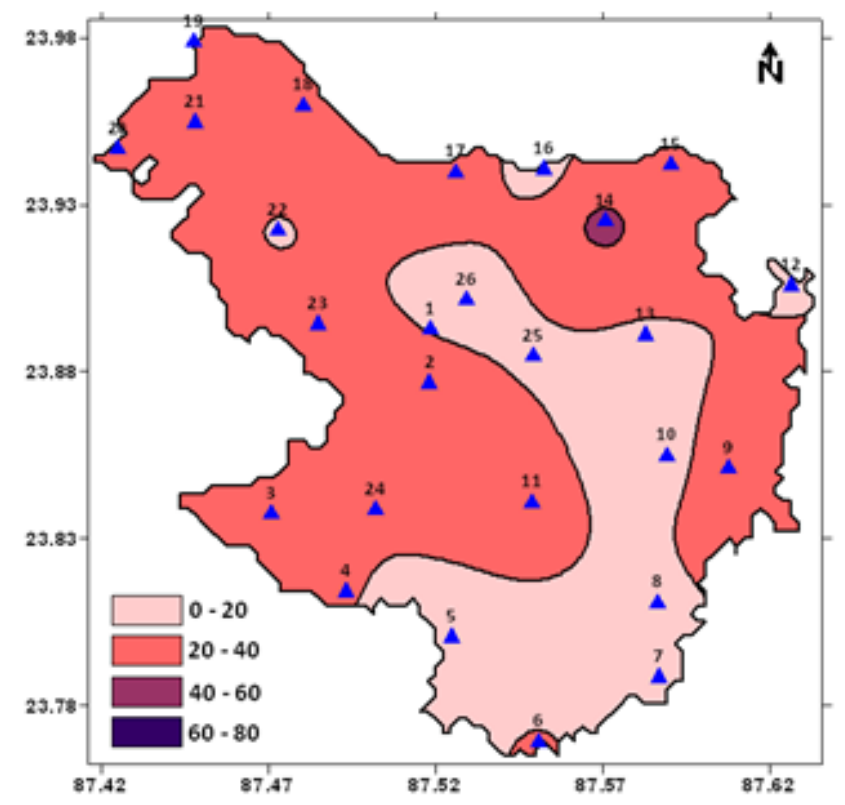

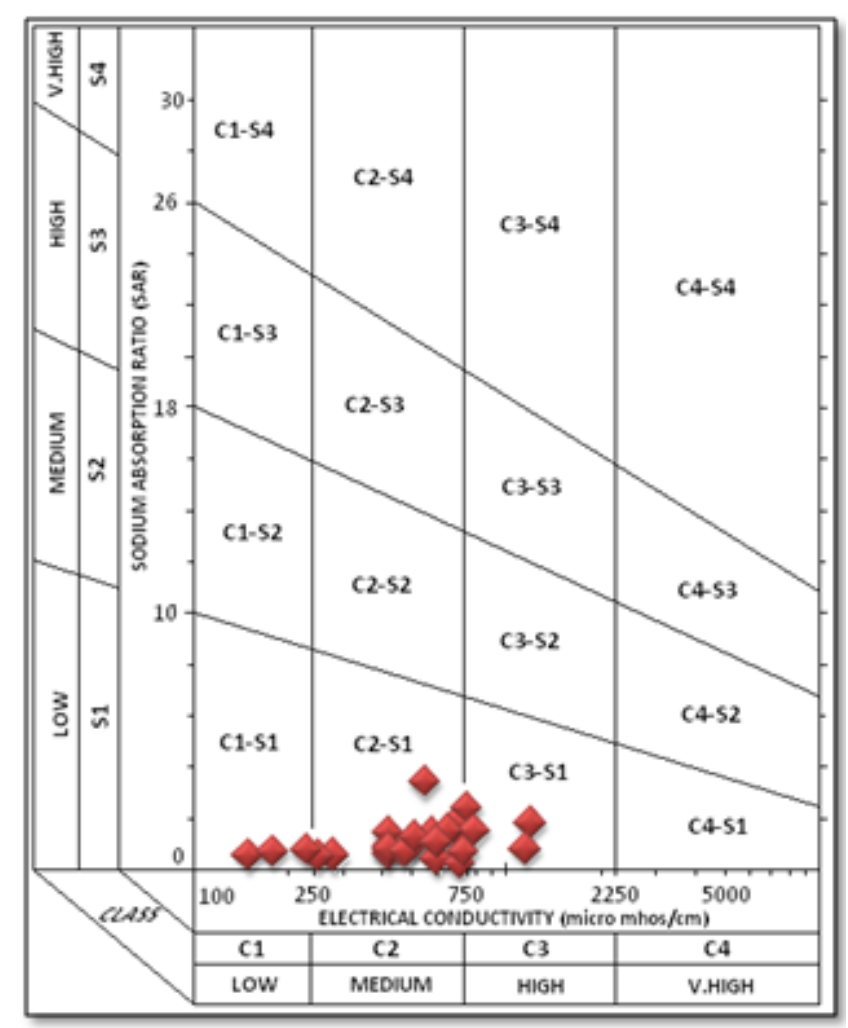

suitability quotient. The sodium adsorption ratio (SAR) was calculated using the following equation:

$$
\mathrm{SAR}=\left[\mathrm{Na}^{+}\right] /\left\{\left(\left[\mathrm{Ca}^{2+}\right]+\left[\mathrm{Mg}^{2+}\right]\right) / 2\right\}^{1 / 2}(1)[49]
$$

Where, concentrations of all ions have been expressed in meq/L.

(Figure 14a and Figure 14b), the water samples fall in the C1-S1 and C2-S1 classes (post monsoon) and C1-S1, C2S1 and C3-S1 classes (pre monsoon), and hence can be considered moderately suitable for irrigation.

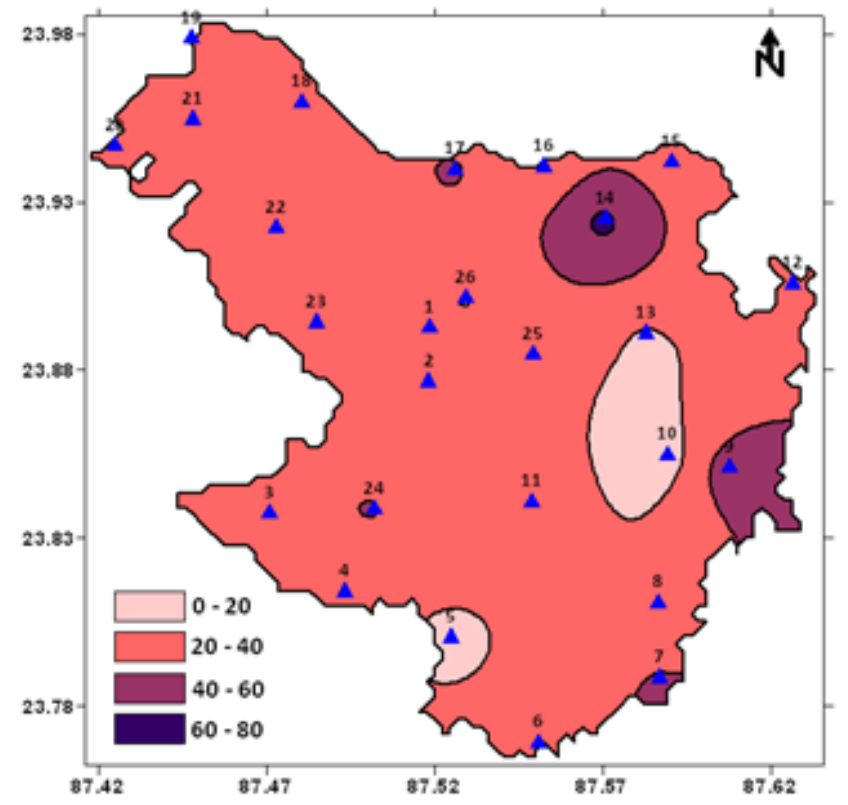

Figure 15. SSP distribution (a. Post monsoon; b. Pre monsoon) 


\subsubsection{Soluble Sodium Percentage (SSP)}

High sodium ion concentration in soil can take a toll on internal drainage patterns in soil as release of calcium and magnesium ions are facilitated due to absorption of sodium by clay particles. Soluble sodium percentage (SSP) was calculated using the following equation:

$\mathrm{SSP}=\left[\left(\mathrm{Na}^{+}+\mathrm{K}^{+}\right) * 100\right] /\left[\mathrm{Ca}^{2+}+\mathrm{Mg}^{2+}+\mathrm{Na}^{+}+\mathrm{K}^{+}\right] \quad(2)[50]$

Where, concentrations of all ions have been expressed in $\mathrm{meq} / \mathrm{L}$.

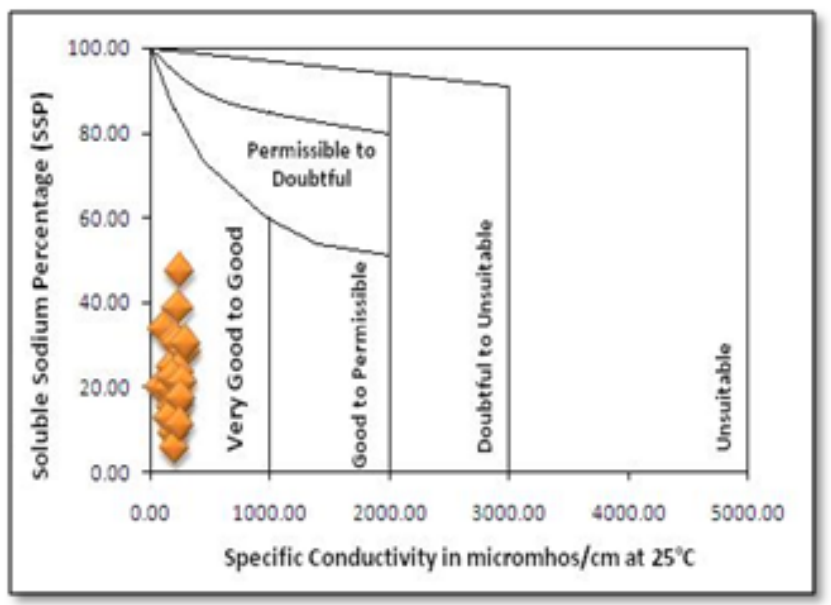

Figure 16. a. Wilcox Diagram for Post monsoon; b. Wilcox Diagram for Pre monsoon

\subsubsection{Permeability Index (PI)}

Another modified criterion has evolved based on the solubility of salts and the reaction occurring in the soil solution from cation exchange for estimating the quality of agricultural waters [52]. Soil permeability is affected by long-term use of irrigation water and is influenced by - (i) Total dissolved solids, (ii) sodium contents, (iii) bicarbonate content. To incorporate the first three items Doneen had empirically developed a term called, 'Permeability Index' after conducting a series of experiments for which he had used a large number of irrigation waters varying in ionic relationships and concentration [44]. The permeability index is given by the following formula:

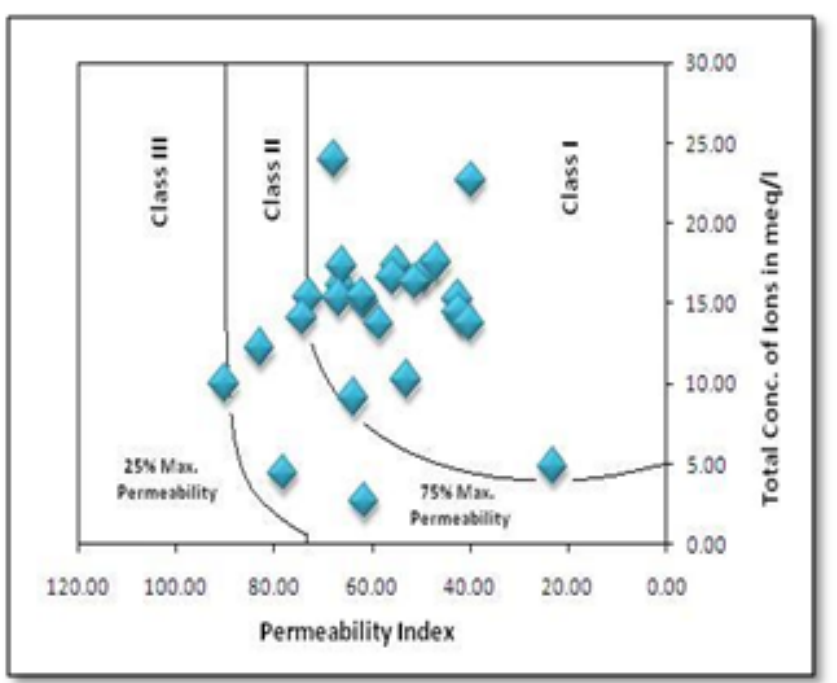

The SSP values range from 5.62 - 47.31in post monsoon and 7.84 - 66.3 during pre monsoon. Figure 15a and Figure 15b present the spatial distribution maps of SSP for post monsoon and pre monsoon sessions respectively. Purandarpur and Dhalla are the locations from where minimum and maximum values of SSP have been reported respectively during both sampling sessions. The SSP values and the EC values have been plotted on the Wilcox diagram [51] (Figure 16a and Figure 16b) and are found to fall under the "Very Good to Good" and "Good to Permissible" categories during post and pre monsoon respectively.

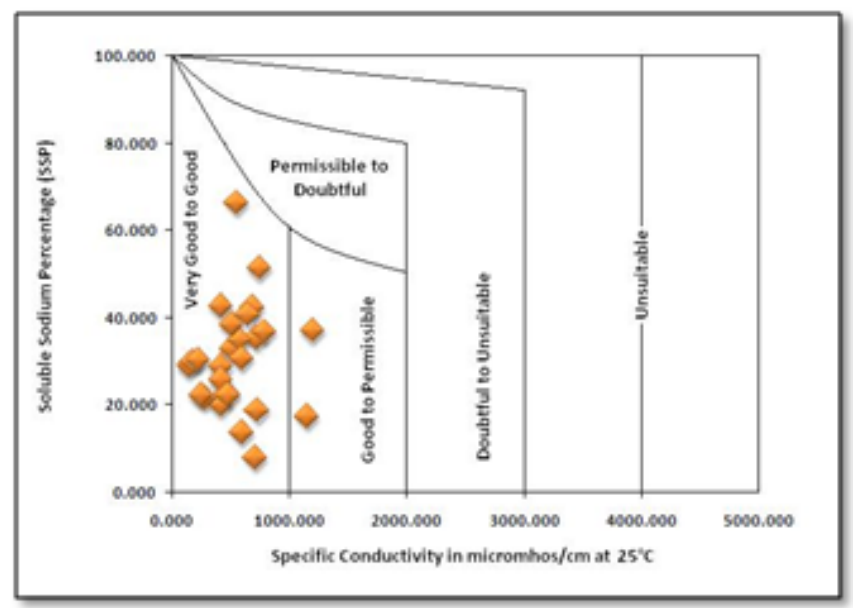

$$
\mathrm{PI}=\mathrm{Na}^{+}+\left[\left\{\left(\mathrm{HCO}_{3}{ }^{-}\right)^{1 / 2} /\left(\mathrm{Ca}^{2+}+\mathrm{Mg}^{2+}+\mathrm{Na}^{+}\right)\right\} * 100\right]
$$

Where, the ions are expressed in meq/L.

Permeability index varies from 23.07 (at Khatangadi) 90.06 (at Aamgachi) in post-monsoon and from 18.20 (at Bhagabanbati) - 66.09 (at Abdarpur) in pre-monsoon. Doneen's chart for post and pre monsoon sessions have been presented in Figure 17a and Figure 17b respectively. PI is classified under Class I ( $>75 \%$ permeability), Class II (25-75\% permeability) and Class III $(<75 \%$ permeability) orders. Class I and Class II waters are categorized as good for irrigation and Class III waters are unsuitable with $25 \%$ of maximum permeability.

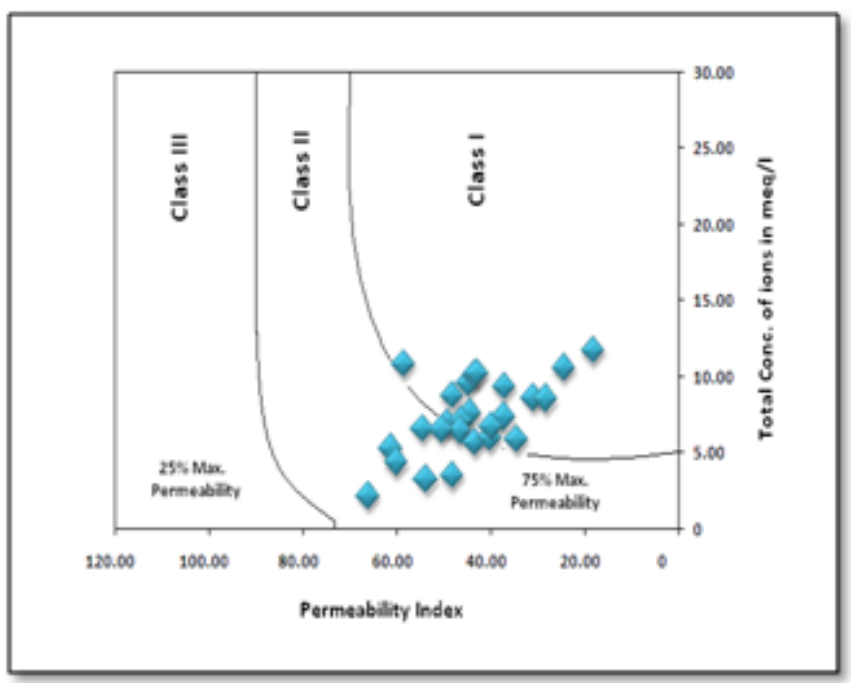

Figure 17. Doneen’s Chart for P.I. values (a. Post monsoon; b. Pre monsoon) 


\subsubsection{Residual Sodium Carbonate (RSC)}

The residual sodium carbonate index (defined by equation 4) of water/soil signifies the alkalinity hazard posed by it and it finds the suitability of water for irrigation in case of clay soils [53].

$$
\mathrm{RSC}=\left(\mathrm{HCO}_{3}{ }^{-}+\mathrm{CO}_{3}{ }^{2-}\right)-\left(\mathrm{Ca}^{2+}+\mathrm{Mg}^{2+}\right)
$$

Where, concentrations of all ions have been expressed in meq/L.

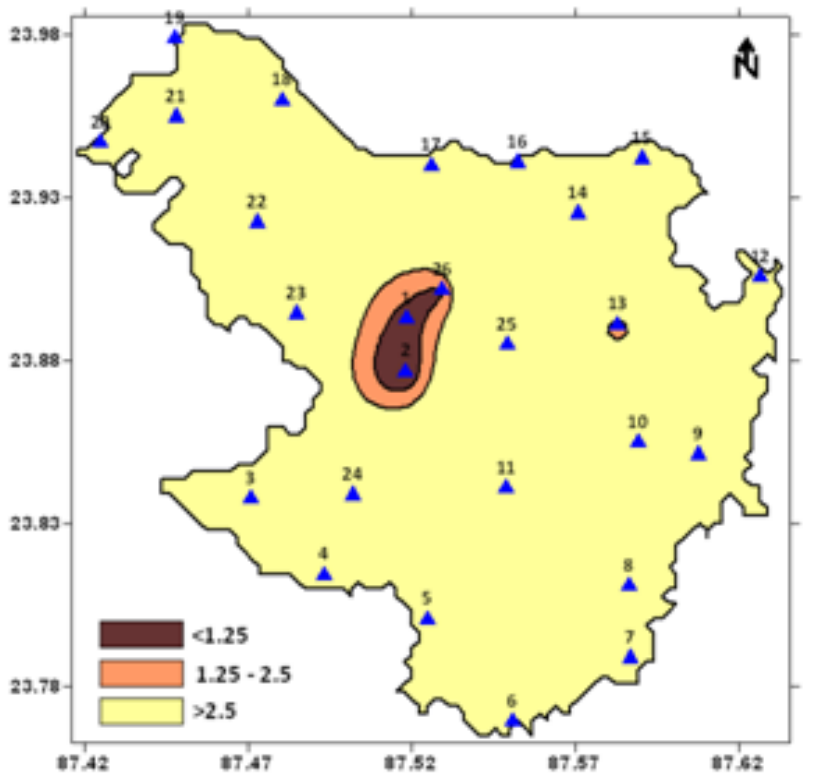

Residual sodium carbonate values should be preferably less than 1.25 to be rendered suitable for irrigational purposes and hence in the present study where RSC values range between $-0.10-12.97$ and more than $80 \%$ of the water samples have RSC > 2.5 (Figure 18a and Figure 18b); it can be concluded that water in this area poses an alkaline hazard to the soil during post monsoon period. In the pre monsoon period though $76 \%$ of RSC values fall in the safe category, indicating localized hazard.

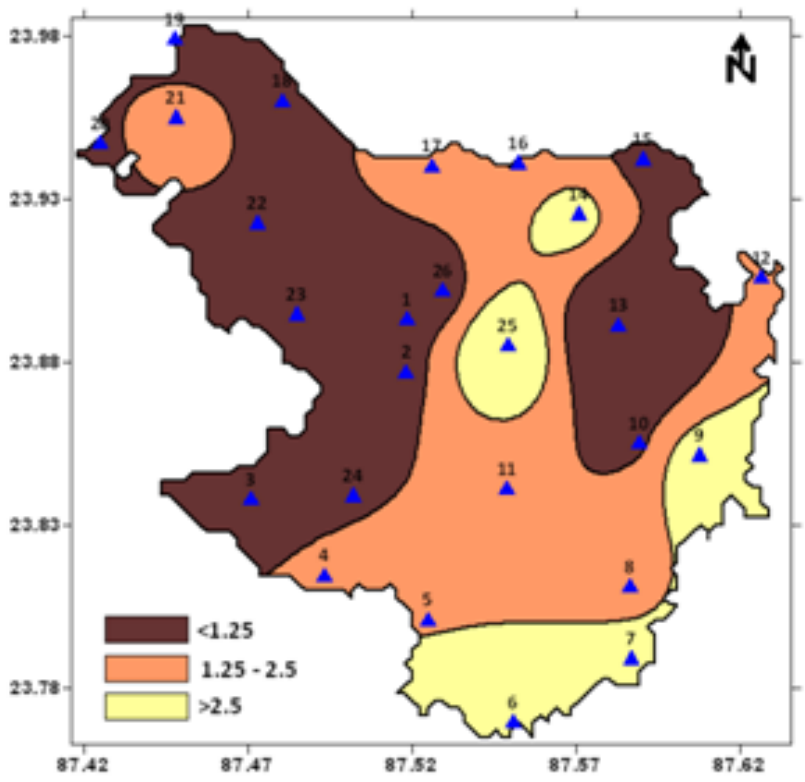

Figure 18. RSC distribution (a. Post monsoon; b. Pre monsoon)

\subsubsection{Magnesium Adsorption Ratio (MAR)}

Generally in most groundwaters $\mathrm{Ca}^{2+}$ and $\mathrm{Mg}^{2+}$ maintain a state of equilibrium [46]. During equilibrium more $\mathrm{Mg}^{2+}$ in groundwater adversely affects the soil quality rendering it alkaline which result in decrease of crop yield [54]. Paliwal developed an index for calculating the magnesium hazard called magnesium adsorption ratio (MAR) [55]. MAR is calculated using the formula:

$$
\text { MAR }=\left(\mathrm{Mg}^{2+* 100}\right) /\left(\mathrm{Ca}^{2+}+\mathrm{Mg}^{2+}\right)
$$

Where, concentrations of all ions have been expressed in $\mathrm{meq} / \mathrm{L}$.

MAR categorizes water into two broad classes - water having MAR $<50$ is considered suitable for irrigation whereas water with MAR > 50 is considered unsuitable, based on which it can be concluded that almost two thirds of the water samples are suitable for irrigation in post monsoon (Figure 19a). During pre monsoon MAR values change rendering about half of the samples suitable for irrigation (Figure 19b).

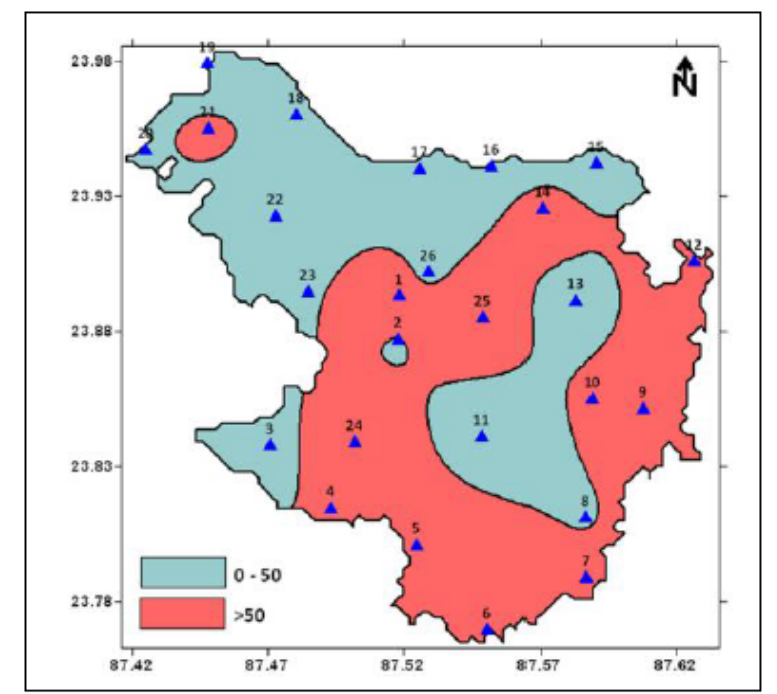

Figure 19. Spatial distribution of MAR (a. Post monsoon; b. Pre monsoon) 


\subsubsection{Kelly's Ratio (KR)}

Kelly's Ratio (defined by equation 6) was devised by Kelly and is measured considering sodium ion concentration against calcium and magnesium ion concentrations [56].

$$
\mathrm{KR}=\mathrm{Na}^{2+} /\left(\mathrm{Ca}^{2+}+\mathrm{Mg}^{2+}\right)
$$

Where, concentrations of all ions have been expressed in $\mathrm{meq} / \mathrm{L}$.

Waters with a KI value $<1$ are considered suitable for irrigation, while those with greater ratios are rendered unsuitable. During post monsoon KR values vary between $0.05-0.87$ and during pre-monsoon the values vary between 0.08 - 1.95. According to Kelly's ratio water analyzed is suitable for irrigation during both periods barring two locations in pre monsoon.

\subsection{Water Quality for Drinking Purposes}

In large and specially semi urban or rural parts of our country groundwater sources in form of dug wells or bore wells are the only source of drinking water. In the present study, to ascertain whether or not the water consumed by villagers meet the drinking water standards, the Total Hardness (TH) of samples have been measured and the use of Hydrogeochemical facies (Piper diagram) and Water Quality Index have been made.

\subsubsection{Total Hardness}

Water hardness has no known adverse effects; however, some evidence indicates its role in heart disease [45]. Hard water is unsuitable for domestic use and it is a measure of the $\mathrm{Ca}^{2+}$ and $\mathrm{Mg}^{2+}$ content expressed in equivalent of calcium carbonate. Hardness of water (temporary and permanent) is by the inhibition of soap action in water due to the precipitation of $\mathrm{Ca}^{2+}$ and $\mathrm{Mg}^{2+}$ salts like carbonates, sulfates and chlorides. Temporary hardness is mainly due to the presence of calcium carbonate and gets removed when water is boiled. Permanent hardness is caused by the presence of $\mathrm{Ca}^{2+}$ and $\mathrm{Mg}^{2+}$ which gets removed by ion exchange processes. Hardness of water in case of industrial purposes may cause scaling of pots, boilers and irrigation pipes and in humans health problems such as kidney failure [45] might occur at extreme levels. The total hardness in $\mathrm{mg} / \mathrm{L}$ is determined by the following equation [50].

$$
\mathrm{TH}(\mathrm{mg} / \mathrm{L})=2: 497 \mathrm{Ca}^{2+}+4: 115 \mathrm{Mg}^{2+}
$$

During post-monsoon, total hardness (TH) ranges between 55.0 to $365.0 \mathrm{mg} / \mathrm{L}$ with an average of $206.9 \mathrm{mg} / \mathrm{L}$, and during pre-monsoon, it ranges between 48.0 to $384.0 \mathrm{mg} / \mathrm{L}$ with an average of $148.3 \mathrm{mg} / \mathrm{L}$. Covering the two sampling sessions, most of the water samples were found to be moderately hard in nature with exceptions of a few hard to very hard types as well.

\begin{tabular}{|c|c|c|c|c|c|c|}
\hline \multirow{2}{*}{ Parameters } & \multirow{2}{*}{ Range } & \multirow{2}{*}{ Class } & \multicolumn{2}{|c|}{ No. of samples } & \multicolumn{2}{|c|}{ Percentage of samples } \\
\hline & & & Post-monsoon & Pre-monsoon & Post-monsoon & Pre-monsoon \\
\hline \multirow{5}{*}{ SAR } & $<20$ & Excellent & 26 & 26 & 100 & 100 \\
\hline & $20-40$ & Good & 0 & 0 & 0 & 0 \\
\hline & $40-60$ & Permissible & 0 & 0 & 0 & 0 \\
\hline & $60-80$ & Doubtful & 0 & 0 & 0 & 0 \\
\hline & $>80$ & Unsafe & 0 & 0 & 0 & 0 \\
\hline \multirow{5}{*}{$\begin{array}{c}\text { EC } \\
\text { WHO (2008) }\end{array}$} & $<250$ & Excellent & 20 & 14 & 77 & 54 \\
\hline & $250-750$ & Good & 6 & 12 & 23 & 46 \\
\hline & $750-2000$ & Permissible & 0 & 0 & 0 & 0 \\
\hline & $2000-3000$ & Doubtful & 0 & 0 & 0 & 0 \\
\hline & $>3000$ & Unsuitable & 0 & 0 & 0 & 0 \\
\hline \multirow{4}{*}{$\begin{array}{c}\text { TH } \\
\text { (Sawyer and McCarty, 1967) }\end{array}$} & $<75$ & Soft & 1 & 2 & 4 & 8 \\
\hline & $75-150$ & Moderate & 4 & 12 & 15 & 46 \\
\hline & $150-300$ & Hard & 19 & 11 & 73 & 42 \\
\hline & $>300$ & Very Hard & 2 & 1 & 8 & 4 \\
\hline \multirow{3}{*}{ RSC } & $<1.25$ & Safe & 16 & 14 & 61 & 54 \\
\hline & $1.25-2.50$ & Marginally suitable & 9 & 7 & 35 & 27 \\
\hline & $>2.50$ & Unsuitable & 1 & 5 & 4 & 19 \\
\hline \multirow{2}{*}{ MAR } & $<50$ & Suitable & 19 & 14 & 73 & 54 \\
\hline & $>50$ & Unsuitable & 7 & 12 & 27 & 46 \\
\hline \multirow{2}{*}{ SSP } & 200 & Suitable & 26 & 26 & 100 & 100 \\
\hline & $>200$ & Unsuitable & 0 & 0 & 0 & 0 \\
\hline \multirow{2}{*}{ KR } & $<1.0$ & Suitable & 26 & 24 & 100 & 92 \\
\hline & $>1.0$ & Unsuitable & 0 & 2 & 0 & 8 \\
\hline \multirow{3}{*}{ PI } & $<80$ & Good & 26 & 26 & 100 & 100 \\
\hline & $80-100$ & Moderate & 0 & 0 & 0 & 0 \\
\hline & $100-120$ & Poor & 0 & 0 & 0 & 0 \\
\hline \multirow{5}{*}{ WQI } & $0-25$ & Excellent & 19 & 8 & 73 & 31 \\
\hline & $26-50$ & Good & 4 & 8 & 15 & 31 \\
\hline & $51-75$ & Poor & 2 & 3 & 8 & 12 \\
\hline & $76-100$ & Very Poor & - & 4 & - & 15 \\
\hline & $>100$ & Unfit for Drinking & 1 & 3 & 4 & 11 \\
\hline
\end{tabular}

Table 4. Classification of Samples according to Standards specified for Water Quality Indices 
Table 4 represents classification of samples according to standards specified for different water quality parameters [57]. Figure 20a and Figure 20b below are

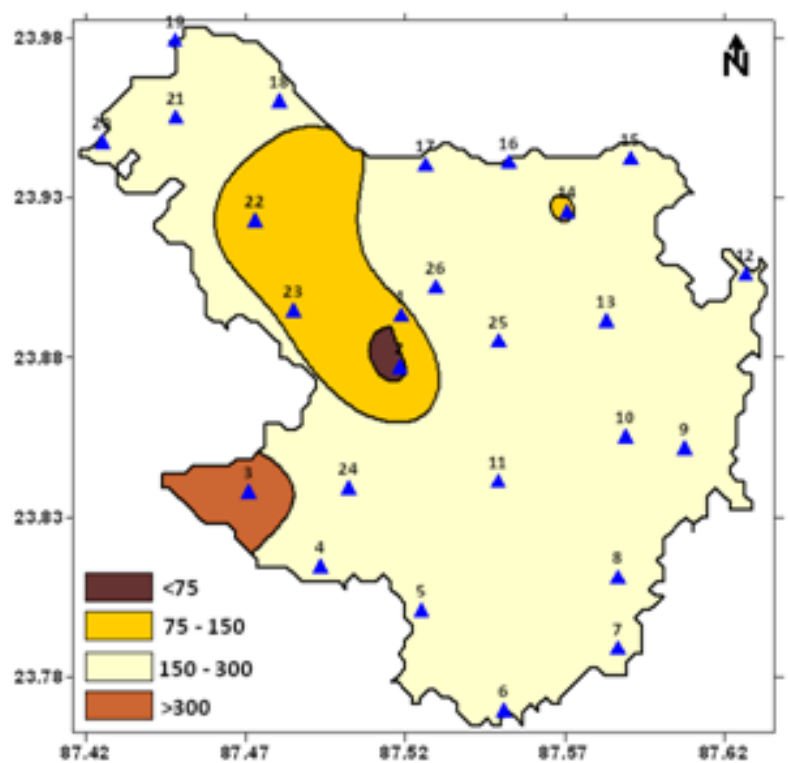

maps where distribution of water hardness in the study area has been portrayed for the post monsoon and pre monsoon sampling sessions respectively.

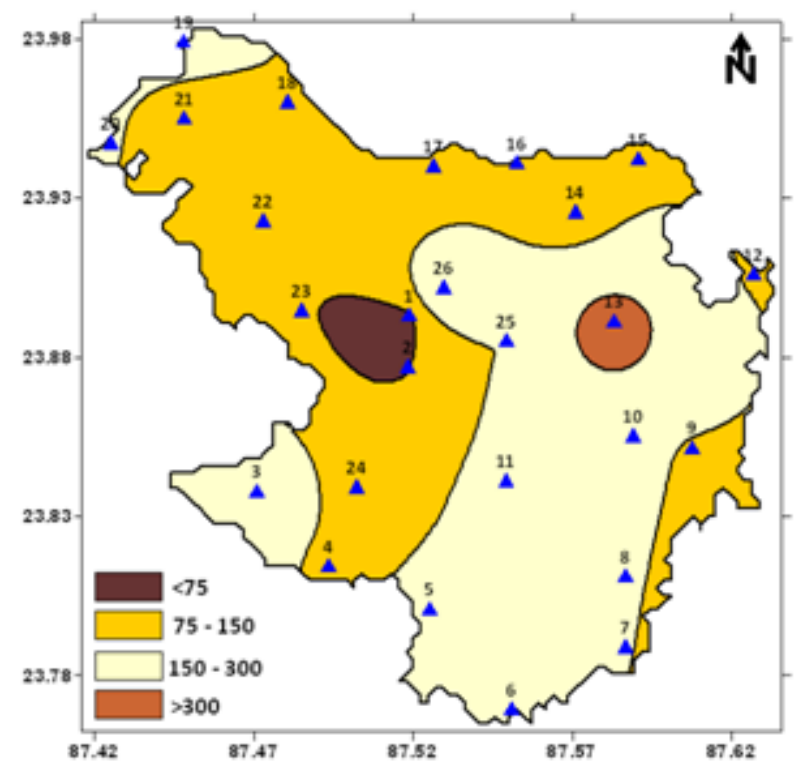

Figure 20. TH distribution (a. Post monsoon; b. Pre monsoon)

\subsubsection{Hydrogeochemical Facies}

The hydrochemical evolution of groundwater can be understood by plotting the major cations and anions present in groundwater, over the Piper Trilinear diagram [58]. This diagram reveals similarities and differences among water samples because those with similar qualities will tend to plot together as groups [50]. This diagram is useful in bringing out chemical relationships among water in more definite terms [59,60,61]. Major ions are plotted as cation and anion in percentages of mili-equivalents in two base triangles.

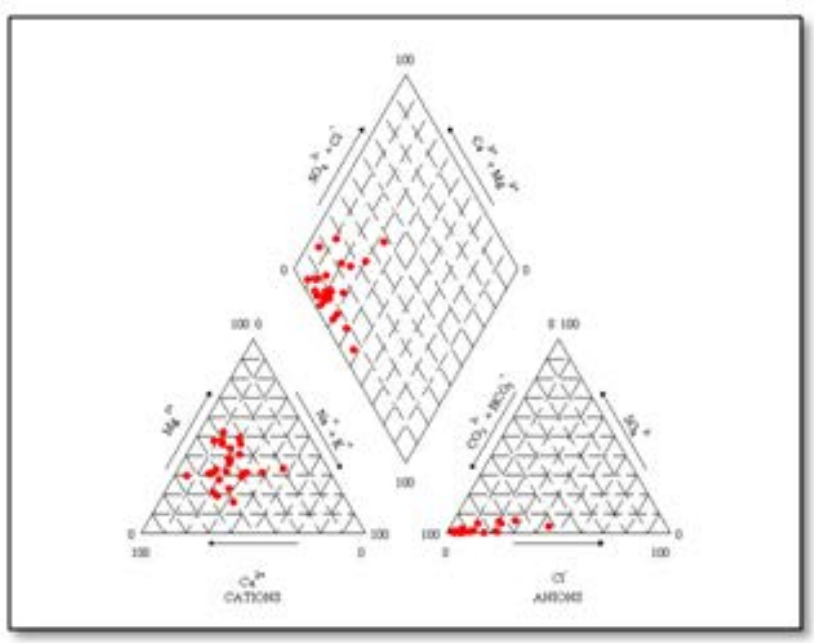

A Piper Trilinear diagram is a graphical representation classifying water based on the dominant presence of cations and anions and has widespread use to assess the water type. Piper diagram can predict the water type in three ways - fresh type, sulfate type and saline type. In Figure 21a and Figure 21b it can be seen the water samples fall under $\mathrm{CaHCO}_{3}$ or the bicarbonate type during post monsoon whereas during pre monsoon groundwater in certain locations falls under the Ca-Mg-Cl-SO $\mathrm{S}_{4}$ type as well.

Figure 21. Piper Trilinear Diagram (a. Post monsoon; b. Pre monsoon)

\subsubsection{Water Quality Index (WQI)}

The contamination status of groundwater and whether or not it is suitable for consumption can be determined with help of a quality index measure [62]. For evaluation of WQI, the analyzed, standard and permissible values of ions present in water have been considered to calculate the quality rating of a water sample.

$$
\mathrm{WQI}=\text { Antilog }\left[\mathrm{W}_{\mathrm{n}=1}^{\mathrm{n}} \log _{10} \mathrm{q}_{\mathrm{n}}\right]
$$

Where: W - Weightage Factor; q - Quality rating

$$
\mathrm{W}_{\mathrm{n}}=\mathrm{K} / \mathrm{S}_{\mathrm{n}}
$$

Where, the proportionality constant, 


$$
\mathrm{K}=\left[1 /\left(\sum_{\mathrm{n}=1}^{\mathrm{n}} 1 / \mathrm{S}_{\mathrm{i}}\right)\right]
$$

Where, $S_{n}$ and $S_{i}$ are the standard / permissible values of water quality parameters, proposed by WHO or ICMR.

Quality rating,

$$
\mathrm{q}=\left\{\left[\left(\mathrm{V}_{\text {actual }}-\mathrm{V}_{\text {ideal }}\right) /\left(\mathrm{V}_{\text {standard }}-\mathrm{V}_{\text {ideal }}\right)\right] * 100\right\}
$$

Where, $\mathrm{V}_{\text {actual }}=$ Analytical value of $\mathrm{i}^{\text {th }}$ parameter obtained from laboratory analysis

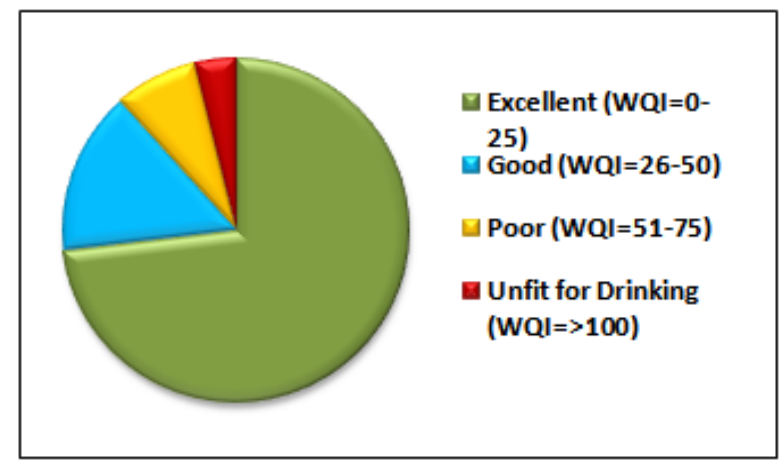

$\mathrm{V}_{\text {standard }}=\mathrm{WHO} /$ ICMR standard of $\mathrm{i}^{\text {th }}$ parameter

$\mathrm{V}_{\text {ideal }}=$ Value of $\mathrm{i}^{\text {th }}$ parameter obtained from standard tables $\left(\mathrm{V}_{\text {ideal }}=0\right.$ for all parameters except $\mathrm{pH}$ where $\mathrm{V}_{\text {ideal }}$ $=7)$.

In Table 4 the range of WQI values according to which the five classes it defines have been shown. The pie charts presented in Figure 22a and Figure 22b depict the categorization of groundwater samples according to WQI classes for post monsoon and pre monsoon sessions respectively.

Figure 22. Categorization of groundwater WQI (a. Post monsoon; b. Pre monsoon)
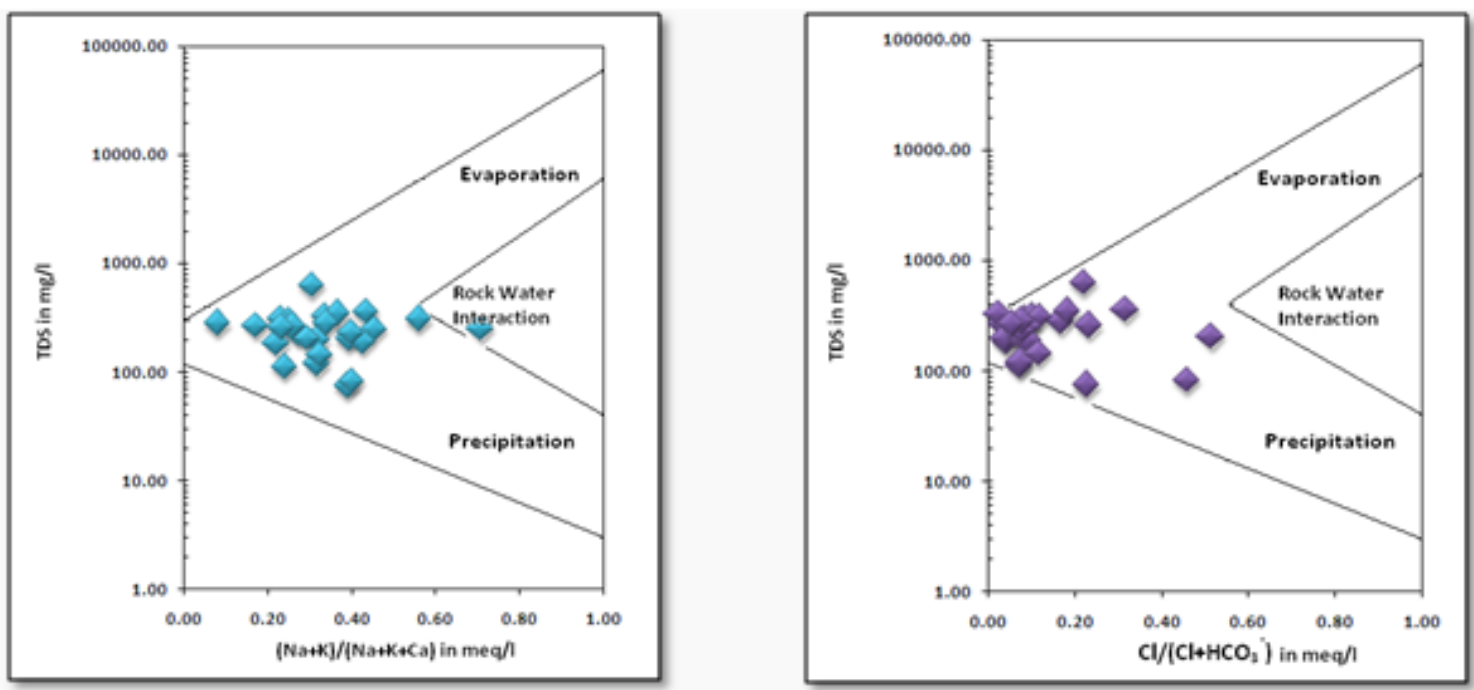

Figure 23. Gibb’s Diagrams (a. Post monsoon; b. Pre monsoon)
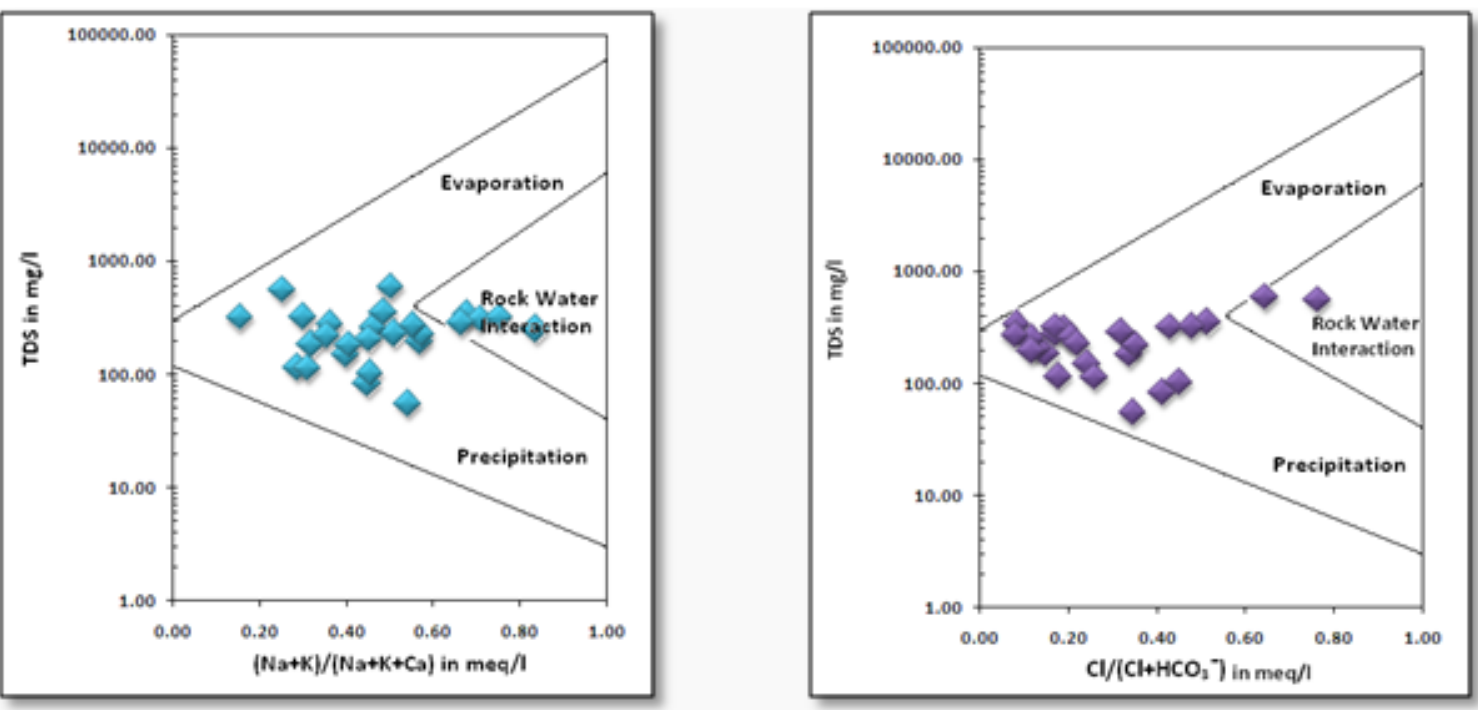

Figure 24. Gibb’s Diagrams (a. Post monsoon; b. Pre monsoon) 


\subsection{Gibb’s Diagrams}

Any one particular process - be it evaporation, precipitation or rock water interaction, which dominantly controls the overall hydrogeochemistry of an area can be identified with the help of the Gibb's Diagram [63]. The Gibb's diagram is prepared using TDS, sodium $\left(\mathrm{Na}^{+}\right)$, potassium $\left(\mathrm{K}^{+}\right)$, calcium $\left(\mathrm{Ca}^{2+}\right)$, chloride $\left(\mathrm{Cl}^{-}\right)$and bicarbonate $\left(\mathrm{HCO}_{3}{ }^{-}\right)$concentrations in groundwater. In Figure 23a, Figure 23b and Figure 24a, Figure 24b the Gibbs's diagrams for post monsoon and pre monsoon sessions have been presented respectively. From these diagrams it can be interpreted that during both sampling sessions rock - water interaction processes significantly control the levels of all chemical constituents in groundwater of the study area. Dissolution and displacement reactions in rocks lining the aquifers are primary reasons behind changing concentrations of major ions in solution.

\subsection{Ionic Balance}

Ionic balance of groundwater or freshwater determines the overall quality of water which is affected by the cationic and anionic concentrations [42]. For calculation of ion - balance in water the concentration of each cation and anion in groundwater sample is calculated in meq/L. The standard formula for calculating ion balance in water is as follows:

$$
\begin{aligned}
& \text { Ion Balance } \\
= & {\left[100 *\left(\sum \text { cation }-\sum \text { anion }\right)\right] /\left[\sum \text { cation }+\sum \text { anion }\right] }
\end{aligned}
$$

Histograms representing ion balance in groundwater samples of the study area have been prepared (Figure 25a, Figure 25b). According to standard rules, the ion balance of a fresh water sample with low TDS is considered to be good if the value is between $-10 \%$ to $+10 \%$. In the post monsoon session ion balance of all water samples barring one, from Singur area, are all negative and less than $-10 \%$, the lowest values being even lesser than $-50 \%$. In pre monsoon, the results are completely opposite. Majority of the water samples (88.5\%) have ion balance values between $-10 \%-+10 \%$. Only three groundwater samples (Bhagabanbati, Gobindopur and Agar) have ion balance values falling outside the desirable range.
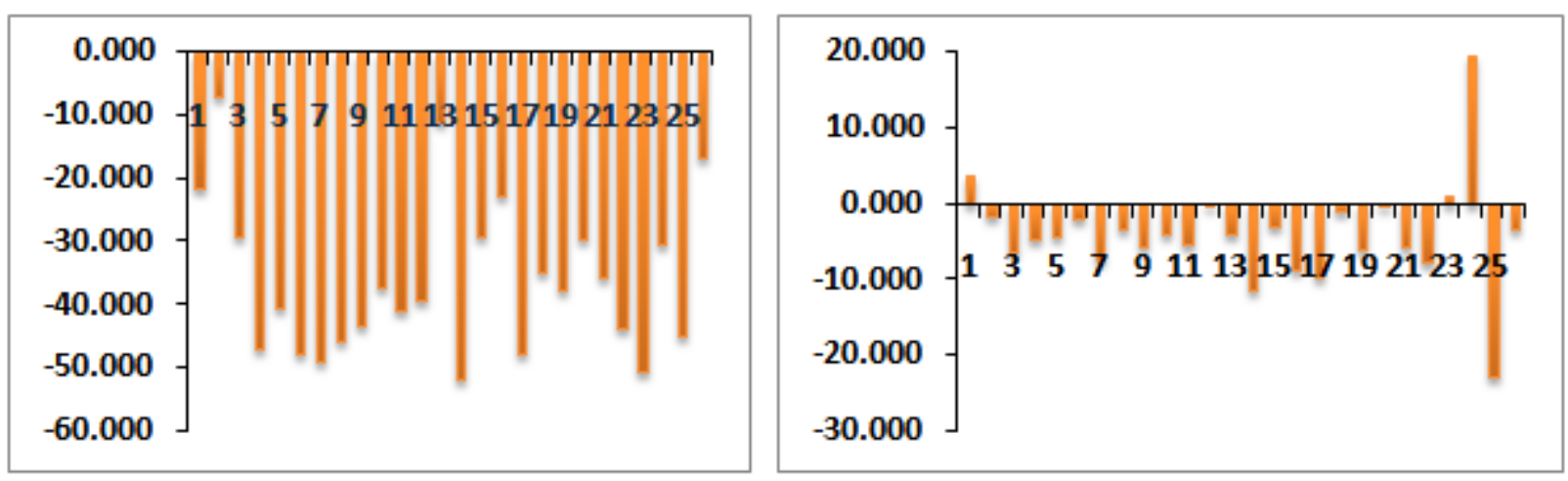

Figure 25. Ion Balance Histogram (a. Post monsoon; b. Pre monsoon)

\section{Conclusion}

The groundwater quality of Suri I and II Blocks of Birbhum District, West Bengal has been assessed for its irrigational and domestic suitability purposes. The quantitative chemical analysis results reflect that the dominant cations in the study area are calcium and sodium and the dominant anions are bicarbonate and chloride. Hydrochemical facies analysis as well the $\mathrm{pH}$ of water, both indicates that groundwater in the area is of alkaline (bicarbonate type) nature. The electrical conductivity values and total dissolved solids values of water samples are all found to be within acceptable limits during both sampling sessions. Most of the water samples were found to be moderately hard in nature with exceptions of a few hard to very hard types.

Based on the water quality parameters analyzed like SAR, SSP, MAR, PI and KR the suitability of groundwater samples for irrigation is good to medium in almost all cases, indicating low sodic waters, but may pose prominent alkaline hazard to soil reflected by the Residual Sodium Carbonate (RSC) values during post monsoon. Most of the water samples have been found to be fit for drinking baring a few in post monsoon whereas in pre monsoon more than one third of samples were found to be unsuitable with regard to drinking. The groundwater will neither cause salinity hazards nor have an adverse effect on the soil properties and are thus largely suitable for irrigational and drinking purposes. Thus the present study reveals that, for most of the parameters, more than $90 \%$ of the total number of samples are within permissible limits of drinking as well as irrigation, with a very few isolated exceptions. Thus it is concluded that the groundwater of the study area is suitable for drinking and irrigation purposes in general.

The results from the water analysis data were used as a tool to identify the process and mechanisms affecting the chemistry of groundwater from the study area. The major ionic concentrations of the area are plotted on the Gibbs' diagram which is used to determine the mechanism controlling the water chemistry (Figure 23a, Figure 23b and Figure 24a, Figure 24b). The samples fall in rock water interaction dominant zone indicating chemical weathering of rock-forming minerals as the prime factor influencing the groundwater quality suggesting dissolution and displacement of minerals constituting the aquifer materials.

\section{Acknowledgments}

The author, S.K. Nag gratefully acknowledges the financial support received from the UGC Major Research 
Project in conducting the field work. The other author (S. Das) is thankful to UGC, New Delhi and Jadavpur University, for providing her the UGC Research Fellowship in Science for Meritorious Student 2012-2013. The authors gratefully acknowledge the support received from Dr. S. Gupta in analyzing the parameters of water quality.

\section{References}

[1] Central Water Commission (CWC) (2006) Water and related statistics. Central Water Commission, Ministry of Water Resources, Government of India, New Delhi.

[2] FAO (2003) The irrigation challenge: increasing irrigation contribution to food security through higher water productivity from canal irrigation systems. IPTRID Issue Paper 4, IPTRID Secretariat, Food and Agricultural Organization of the United Nations, Rome.

[3] Shah T, Molden D, Sakthivadivel R, Seckler D (2000). The global ground water situation: overview of opportunity and challenges. International Water Management Institute, Colombo.

[4] Chatterjee R, Goorab T, Paul S (2010) Groundwater quality assessment of Dhanbad district, Jharkhand, India. Bull Eng Geol Environ 69: 137-141.

[5] Milovanovic M (2007). Water quality assessment and determination of pollution sources along the Axios / Vardar River, Southeast Europe. Desalination 213: 159-173.

[6] Vasanthavigar M, Srinivasamoorthy K, Gandhi R, Chidambaram S, Vasudevan S (2010) Application of water quality index for groundwater quality assessment: Thirumanimuttur sub-basin Tamilnadu, India. Env. Monit. Assess. 171 (1-4): 595-609.

[7] Sreedevi PD (2004) Groundwater quality of Pageru river basin. Cuddapah district, Andhra Pradesh. J Geol.Sc. India 64: 619-636 (2004).

[8] Subramani T, Elango L, Dhamodarasamy SR (2005) Groundwater quality and its suitability for drinking and agricultural use in Chithar River Basin, Tamilnadu, India. Environ Geo 47: 10991110.

[9] Schiavo MA, Havser S, Gusimano G, Gatto L (2006) Geochemical characterization of groundwater and sub-marine discharge in the southeastern Sicily. Continental Sshelf Research, 26 (7): 826-834.

[10] Aghazadeh N, Mogaddam AA (2010) Assessment of groundwater quality and its suitability for drinking and agricultural uses in the Oshnavieh area, Northwest of Iran. J Environ Prot 1: 30-40.

[11] Domenico PA (1972) Concepts and models in groundwater hydrology. McGraw-Hill, New York.

[12] Schuh WM, Klinekebiel DL, Gardner JC, Meyar RF (1997) Tracer and nitrate movements to groundwater in the Norruem Great Plains. J Environ Qual 26:1335-1347.

[13] Hussein MT (2004) Hydrochemical evaluation of groundwater in the Blue Nile Basin, eastern Sudan, using conventional and multivariate techniques. Hydrogeol J 12: 144-158.

[14] Al-Futaisi A, Rajmohan N, Al-Touqi S (2007) Groundwater quality monitoring in and around Barka dumping site, Sultanate of Oman. The Second IASTED (The International Association of Science and Technology for Development) International Conference on Water Resources Management (WRM 2007), Honolulu, Hawaii, USA, 20-22 August.

[15] Jalali M (2007) Hydrochemical identification of groundwater resources and their changes under the impacts of human activity in the Chah basin in western Iran. Environ Monit Assess 130: 347364.

[16] Pritchard M, Mkandawire T, O’Neill JG (2008) Assessment of groundwater quality in shallow wells within the southern districts of Malawi. Phys Chem Earth 33: 812-823.

[17] Rivers CN, Hiscock KM, Feast NA, Barrett MH, Dennis PF (1996) Use of nitrogen isotopes to identify nitrogen contamination of the Sherwood sandstone aquifer beneath the city of Nottingham, UK. Hydrol J 4(1): 90-102.

[18] Srinivasamoorthy K, Chidambaram S, Vasanthavigar M (2008) Geochemistry of fluorides in groundwater: Salem District, Tamil Nadu, India. J Environ Hydrol 1:16-25.

[19] Ma J, Ding Z, Wei G, Zhao H, Huang T (2009) Sources of water pollution and evolution of water quality in theWuwei basin of
Shiyang River, Northwest China. J Environ Manage 90: 11681177.

[20] Mohan R, Singh AK, Tripathi JK, Chowdhary GC (2000) Hydrochemistry and quality assessment of groundwater inNaini Industrial area, Allahabad district, Uttar Pradesh. J Geol Soc India 55: 77-89.

[21] Subba Rao N, Prakasa Rao J, John Devadas D, Srinivasa Rao KV, Krishna C, Nagamalleswara Rao B (2002) Hydrogeochemistry and groundwater quality in a developing urban environment of a semiarid region, Guntur, Andhra Pradesh. J Geol Soc India 59: 159-166.

[22] Ahmed SS, Mazumder H, Jahan CS, Ahmed M, Islam S (2002) Hydrochemistry and classification of groundwater, Rajshahi City Corporation Area, Bangladesh. J Geol Soc India 60: 411-418.

[23] Bathrellos GD, Skilodimou HD, Kelepertsis A, Alexakis D, Chrisanthaki I, Archonti D (2008) Environmental research of groundwater in the urban and suburban areas of Attica region, Greece. Environ Geol 56: 11-18.

[24] Anku YS, Banoeng-Yakubo B, Asiedu DK, Yidana SM (2009) Water quality analysis of groundwater in crystalline basement rocks, northern Ghana. Environ Geol 58: 989-997.

[25] Kumar M, Kumari K, Singh UK, Ramananthan AL (2009) Hydrogeochemical processes in the groundwater environment of Muktsar, Punjab: conventional graphical and multivariate statistical approach. Environ Geol 57: 873-884.

[26] Wen XH, Wu YQ, Wu J (2008) Hydrochemical characteristics of groundwater in the Zhangye basin, northwestern China. Environ Geol 55: 1713-1724.

[27] Stamatis G, Lambrakis N, Alexakis D, Zagana V (2006) Groundwater quality in Mesogea basin in eastern Attica (Greece). Hydrol Process 20: 2803-2818.

[28] Pachero J, Marin L, Cabrera A, Steinich B, Escolero O (2001) Nitrate temporal and spatial patterns in 12 water-supply wells, Yucatan, Mexico. Environ Geol 40: 708-715.

[29] Antoniou V (2002) Natural and human environment of Athens basin. Paper presented at the 6th Geographical conference of the Hellenic Geographical Society, Thessaloniki, I. pp. 311-318.

[30] Nag SK, Lahiri A (2012) Hydrochemical Characteristics of Groundwater for Domestic and Irrigation Purposes in Dwarakeswar Watershed area, India. American Journal of Climate Change 1, 217-230.

[31] Nag SK, Ghosh P (2013) Variation in Groundwater Levels and Water Quality in Chhatna Block, Bankura District, West Bengal A GIS Approach. Jour Geol. Soc. India. 81 (2), pp.261-280.

[32] Nag SK, Saha S (2014). Integration of GIS and remote sensing in groundwater investigations: A case study in Gangajalghati Block, Bankura District, West Bengal, India. Arabian Journal for Science and Engineering.

[33] Nag SK (2014). Evaluation of hydrochemical parameters and quality assessment of the groundwater in Gangajalghati Block, Bankura District, West Bengal, India. Arabian Journal for Science and Engineering.

[34] Prasanna MV, Chidambaram S, Gireesh TV, Jabir Ali TV (2010) A study on hydrochemical characteristics of surface and subsurface water in and around Perumal Lake, Cuddalore district, Tamil Nadu, South India. Environ Earth Sci.

[35] Tyagi SK, Datta PS, Pruthi NK (2009) Hydrochemical appraisal of groundwater and its suitability in the intensive agricultural area of Muzaffarnagar district, Uttar Pradesh, India. Environ Geol 56: 901-912.

[36] Laluraj CM, Gopinath G (2006) Assessment on seasonal variation of groundwater quality of phreatic aquifers-A river basin system. Environ Monit Assess 117: 45-47.

[37] Nagarajan R, Rajmohan N, Mahendran N, Senthamilkumar S (2009) Evaluation of groundwater quality and its suitability for drinking and agricultural use in Thanjavur city, Tamil Nadu, India. Environ Monit Assess.

[38] Jeevanandam M, Kannan R, Srinivasalu S, Rammohan V (2006) Hydrogeochemistry and Groundwater Quality Assessment of Lower Part of the Ponnaiyar River Basin, Cuddalore District, South India. Environ Monit Assess 132(1-3):263-274.

[39] Freeze RA, Cherry JA (1979) Groundwater. Prentice, HallEnglewood Cliffs, p 604.

[40] UNESCO (2007). Water portal newsletter no. 161: Water related diseases. Available at: http:/www.unesco org/water/news/ newsletter/161.shtml.

[41] APHA (American Public Health Association) (1995) Standard Methods for Examination of Water and Waste Water. American 
Public Health Association, American Water Works Association and Water Pollution Control Federation, Washington DC, USA.

[42] Huh Y, Tsoi MY, Zaitiser A, Edwards JN (1998). The fluvial geochemistry of the river of eastern Siberia. I. Tributaries of Lena River draining the sedimentation platform of the Siberia Craton. Geochem. Cosmochem. Acta 62: 1657-1676.

[43] U.S. Salinity Lab (1954) Saline and Alkali Soils - Diagnosis and Improvement of U.S. Salinity Laboratory. Agriculture Hand Book No.60, Washington.

[44] Doneen LD (1964) Water quality for agriculture. Department of irrigation, University of California. Davis. pp. 48.

[45] WHO (2008) Guidelines for drinking-water quality: incorporating first and second addenda, Recommendations, 3rd edition, WHO Press, v.1, 668p.

[46] Hem JD (1985) Study and interpretation of the chemical characteristics of natural water, 3rd edn. Scientific Publishers, Jodhpur, p.2254.

[47] Ayers RS, Westcot DW (1994) Water quality for agriculture: FAO Irrigation and Drainage Paper 29. Revision. 1. pp. 1-130.

[48] Subba Rao N (2006) Seasonal variation of groundwater quality in a part of Guntur district, Andhra Pradesh, India. Environ Geol 49:413-429.

[49] Richards, L. A. (Ed). (1954). Diagnosis and improvement of saline and alkali soils (p. 160). USDA Hand Book, No. 60.

[50] Todd DK (1980) Ground water hydrology. Wiley, New York, 527p.

[51] Wilcox LV (1955) Classification and use of irrigation waters. USDA, Circular 969, Washington.

[52] Gupta SK, Gupta, IC (1987) Management of Saline Soils and Water. Oxford and IBH Publ. Co., New Delhi, India, 399p.
[53] Raju NJ (2007) Hydrogeochemical parameters for assessment of groundwater quality in the upper Gunjanaeru River basin, Cuddapah District, Andhra Pradesh, South India. Environ Geol 52: 1067-1074.

[54] Kumar M, Kumari K, Ramanathan AL, Saxena R (2007) A comparative evaluation of groundwater suitability for irrigation and drinking purposes in two intensively cultivated districts of Punjab, India. Environ Geol 53: 553-574.

[55] Paliwal KV (1972) Irrigation with saline water, Monogram no. 2 (New series). New Delhi, IARI, p 198.

[56] Kelly WP (1940) Permissible composition and concentration of irrigated waters. In: Proceedings of the ASCF66. p. 607.

[57] Sawyer CN, McCarty PL (1967) Chemistry for sanitary engineers. 2nd Ed., McGraw-Hill, New York, Pp.518.

[58] Piper AM (1994) A graphic procedure in the geochemical interpretation of water analysis. Am Geophys Union Trans 25: 914-923.

[59] Back W (1966) Hydrochemical facies and groundwater flow pattern in northern part of Atlantic Coastal Plain. US Geol Survey Prof Pap 498-A: 42.

[60] Walton WC (1970) Groundwater resources evaluation. McGraw Hill Book Co., New York.

[61] Apambire WB, Boyle DR, Michael FA (1997) Geochemistry, genesis, and health implications of fluoriferous groundwaters in the upper regions of Ghana. Environ Geol 33 (1): 13-24.

[62] Tiwari TN, Mishra MA (1985) A preliminary assignment of water quality index of major Indian rivers. Indian J Environ Prot 5: 276279.

[63] Gibbs RJ (1970) Mechanisms Controlling World's Water Chemistry. Science 170: 1088-1090. 